\title{
Seeing Savings from an ESPC Project in Fort Polk's Utility Bills
}

February 2005

John A. Shonder and Patrick J. Hughes

Oak Ridge National Laboratory 


\section{Contents}

Executive Summary ................................................................................... ii

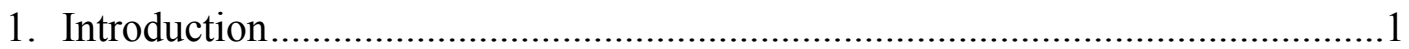

2. When Savings Should or Should Not Be Apparent in Utility Bills ....................1

3. Case Study of Utility Bill Analysis: Fort Polk ESPC Project ............................2

3.1 Fort Polk ESPC Project............................................................................ 3

3.2 ORNL's 1998 Evaluation of the Fort Polk Project ................................... 3

3.3 Data Available for This Case Study ..................................................... 4

3.4 Resolution of Electricity Use Savings from Utility Bill Analysis ............. 5

3.5 Resolution of Reduced Peak Demand from Utility Bill Analysis ............. 7

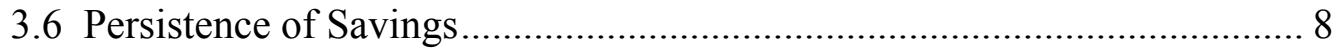

3.7 Resolution of ESPC Cost Savings from Utility Bill Analysis ................. 10

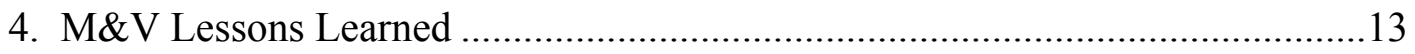

4.1 Risk and Responsibility Matrix.......................................................... 14

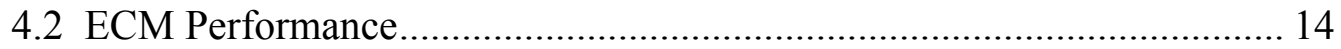

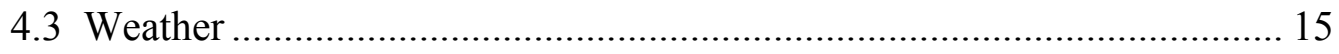

4.4 Energy Loads ............................................................................... 16

4.5 Energy Price Escalation ..................................................................... 18

4.6 Summary of M\&V Best Practices ...................................................... 22

5. Implications for Agencies Deciding to Reconcile ESPC Savings and

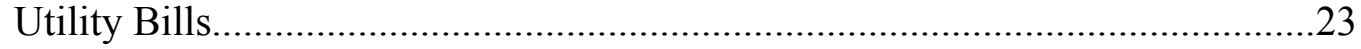

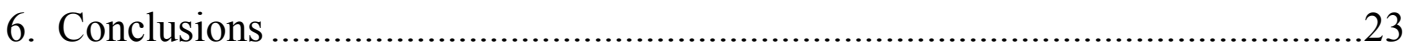

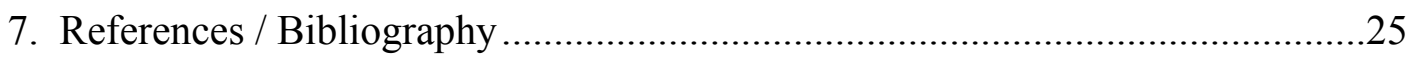

Appendix A: Utility Bill Analysis to Determine Electrical Energy Savings ...... A-1 Appendix B: Utility Bill Analysis to Determine Electricity Demand Savings ....B-1 Appendix C: Analysis to Determine Persistence of Savings ................................1 Appendix D: Utility Bill Analysis to Determine Electrical Cost Savings .......... D-1 


\section{Seeing Savings from an ESPC Project in Fort Polk's Utility Bills}

\section{Executive Summary}

While it is generally accepted that the energy projects implemented by federal agencies save energy and costs, the savings are usually not obvious in the utility bills. This is true for many valid technical reasons, even when savings are verified in other ways to the highest degree of certainty. However, any perceived deficiency in the evidence for savings is problematic when auditors or other observers evaluate energy projects and energy management programs.

Only in rare cases can savings from energy projects be seen in the facility's utility bills, simply as a matter of scale. The typical energy project affecting $25 \%$ of a facility's load and reducing energy use by $20 \%$ would yield a change in the utility bill of only $5 \%$, which is in the same range as variations due to weather. Measurement and verification (M\&V) guidelines published by the U.S. Department of Energy's (DOE's) Federal Energy Management Program (FEMP) recommend against using simple utility bill analysis for any federal energy savings performance contract (ESPC) projects. The M\&V guidelines specify (FEMP 2000, p. 164) that regression modeling is appropriate only when predicted savings are greater than about 10 to $20 \%$ of the site's total monthly metered energy use. Also required are at least 12 and preferably 24 months of preinstallation data to calculate a baseline model, and at least 9 and preferably 12 months of post-installation data to calculate first-year savings.

Utility bill analysis under these circumstances can resolve savings when comparing the periods immediately before and after the retrofits. However, factors that affect energy use change constantly, and those changes compound over the years. After several years it would be impossible through any kind of utility bill analysis to distinguish between the impact of the energy conservation measures (ECMs) and the effects of factors such as operating schedules, occupancy levels, or new or disconnected loads on the energy bill.

In the special case of a large geothermal heat pump (GHP) retrofit at the Army's Fort Polk in 1995 - 1996, the authors' analysis of utility bills does unequivocally confirm and quantify savings. (See the appendices for discussion of analysis methods.) Using utility bills from 12 months immediately before and after the retrofits, we show that the electricity savings are $24.3 \pm 4.0$ million $\mathrm{kWh}$ (a 95\% confidence interval), and that the utility bills predict peak summer demand savings of $7.27 \pm 3.1 \mathrm{MW}$. These results agree with our 1998 evaluation of the project (Hughes and Shonder 1998), which was based on data from 15-minute-interval submetering of the electric distribution feeders serving only the family housing areas, where the project was implemented, not on data from the postwide utility meters. 
Analysis of the utility bill data did indicate that Fort Polk's post-wide annual electricity use increased by about 13 million $\mathrm{kWh}$, or about half of the ESPC project's savings, between the first post-retrofit year (1996-97) and 2002-03. Analysis of data from four feeders serving about $12 \%$ of family housing — a large sample for such an analysis shows that between the first post-retrofit year and 2003-04, electricity use in family housing increased about $2.2 \%$, or $0.31 \%$ per year. This increase, which is far smaller than the increase from plug load growth we predicted in 1998, accounts for about 1 million of the total 13 million $\mathrm{kWh}$ rise in electricity use between 1996 and 2003. The savings due to the GHP retrofits have apparently persisted.

Agencies that decide to correlate the impact of individual ESPC projects directly to changes in their utility bills at the site or agency level will probably need to consider implementing a system for tracking what their utility bills would have been if the energy efficiency projects had not been implemented. Most agencies have tracking systems for their actual energy use and costs across all agency sites, and perhaps these systems could be enhanced for this purpose. However, agencies will have to weigh the value of calculating actual savings against the cost of the required extra effort.

The current state of the art in federal M\&V practices enables the government to costeffectively verify savings to an acceptable degree of certainty, without allocating unmanageable risks to the ESCO that would inevitably burden projects with high pricing and financing costs to compensate for those risks. Generally the ESCO's risks are limited to guaranteeing the performance of the ECMs. Performance is translated into contracted cost savings assuming typical weather, pre-retrofit baseline energy use levels for the loads not affected by the project, and stipulated energy cost escalation rates.

Contracted savings as calculated using stipulated values may differ from actual cost savings in any given year. However, if stipulated values are based on sound assumptions, annual contracted and actual savings will be reasonably similar, and will tend to converge over the contract term. For example, one year's weather will rarely match the average used for the experience-based stipulation, but the weather over time should conform to the average. Our analysis of Fort Polk's utility bills illustrates this effect. When modeled using typical weather and energy price escalation of $0.5 \%$ per year, contracted savings did differ from actual, but the cumulative difference declined over the 6 years analyzed.

An additional margin of safety (and cost savings) is afforded by the fact that ESCOs universally guarantee less than $100 \%$ of estimated savings to increase their certainty of meeting the guarantee. And the fact remains that the ESCO is obligated to compensate the government if the verified contracted cost savings do not match or exceed the guarantee each year.

The alternative to using simplifying assumptions for the purpose of calculating savings is to have the ESCO bear the risk of factors such as the weather, energy rates, and the government's own operating hours affecting savings. This would be a poor and expensive choice for the government. 


\section{Seeing Savings from an ESPC Project in Fort Polk's Utility Bills}

\section{Introduction}

Federal agencies have implemented many energy efficiency projects over the years with direct funding or alternative financing vehicles such as energy savings performance contracts (ESPCs). While it is generally accepted that these projects save energy and costs, the savings are usually not obvious in the utility bills. This is true for many valid technical reasons, even when savings are verified in other ways to the highest degree of certainty. However, any perceived deficiency in the evidence for savings is problematic when auditors or other observers evaluate the outcome of energy projects and the achievements of energy management programs. This report discusses under what circumstances energy savings should or should not be evident in utility bills.

In the special case of a large ESPC project at the Army's Fort Polk, the analysis of utility bills carried out by the authors does unequivocally confirm and quantify savings. The data requirements and methods for arriving at definitive answers through utility bill analysis are demonstrated in our discussion of the Fort Polk project.

The following paragraphs address why the government generally should not expect to see savings from ESPC projects in their utility bills. We also review lessons learned and best practices for measurement and verification $(\mathrm{M} \& \mathrm{~V})$ that can assure best value for the government and are more practical, straightforward, and cost-effective than utility bill analysis.

\section{When Savings Should or Should Not Be Apparent in Utility Bills}

The first problem with seeing energy savings in utility bills is a matter of scale — the magnitude of savings compared to the magnitude of metered energy use. Consider a simplified example - a typical energy efficiency project that affects $25 \%$ of a facility's total load and yields average annual energy savings of 20\%. (Larger projects are rare.) Assuming that all savings and load are electricity and one meter measures the whole site (as is common), then an average change of only $5 \%$ in the utility bill would be expected. A simple comparison of utility bills before and after the project may not show a savings of this magnitude, because variations due to weather are generally in the same range or larger.

In later years, it would become difficult or impossible to isolate the small change attributable to this typical energy project from the normal variation in utility bills, even using sophisticated analysis methods. Over time, many factors in addition to weather contribute to changes in a facility's energy use, such as occupancy rates, operating hours, and acquisition and use of new energy-consuming equipment. These changes are 
compounded over time, and the utility bill provides no information to help distinguish between their effects.

"Utility bill analysis," which encompasses simple utility bill comparison, is included under M\&V Option C as defined in the International Performance Measurement \& Verification Protocol (IPMVP) and the Federal Energy Management Program's (FEMP's) Measurement \& Verification Guidelines (an application of IPMVP to federal energy projects). However, FEMP recommends against depending on simple utility bill comparisons:

“... energy savings evaluations using whole-building or facility-level metered data may be completed using techniques ranging from simple billing comparison to multivariate regression analysis. Utility bill comparison is the use of utility billing data ... and simple mathematical techniques to calculate annual energy savings. Utility bill comparison is a very simple and, typically, unreliable method. It is applicable only to very simple ECMs [energy conservation measures] in which energy use changes are a direct result of [ECM] installation. Therefore, this method is not recommended for most federal ESPC projects." (FEMP 2000, p. 164-165)

Regression modeling of utility billing meter data is an acceptable Option C method of calculating savings, but only when enough data is available and savings represent a large proportion of metered energy use, according to both the FEMP $M \& V$ Guidelines and ASHRAE Guideline 14-2002, Measurement of Energy and Demand Savings. FEMP guidelines specify that regression modeling is appropriate when predicted savings are greater than about 10 to $20 \%$ of the site's energy use at the meter on a monthly basis (p. 164). Also required are at least 12 and preferably 24 months of pre-installation data to calculate a baseline model, and at least 9 and preferably 12 months of post-installation data to calculate first-year savings.

Even when utility bill analysis can reliably establish savings in the period immediately after ECM installation, it is difficult to verify savings persistence over time using this technique because buildings and facilitates are dynamic, and many factors, such as weather, occupancy levels, operating hours, plug loads, new connected loads, disconnected loads, and energy rate changes affect energy usage and cost. Rarely is it possible to track all of these factors over time and adjust and correct the utility bill analysis in order to isolate the savings attributable to an energy project.

The best chance of clearly seeing project impact in a utility bill analysis occurs in cases of very large, comprehensive projects, where the analysis compares periods immediately before and after the retrofit.

\section{Case Study of Utility Bill Analysis: Fort Polk ESPC Project}

The large ESPC project implemented at Fort Polk in 1995 - 96 is an instance where project savings should be apparent in the utility bills when the analysis compares periods immediately before and after the retrofit. The project was a comprehensive retrofit of 4003 family housing units that before the retrofit accounted for about $42 \%$ of Fort Polk's 
total electricity use of about 190 million kWh per year. Since family housing represents such a large share of total electricity use, and the ESPC project resulted in a large reduction in electricity use in family housing $(32.5 \%)$, the post-wide savings of $\sim 14 \%$ resulting from the project should be apparent in the utility bills.

The nature of the Fort Polk project itself, access to historical and current data, and the authors' history with the project present an ideal opportunity to answer these questions:

- Are the ESPC electricity use and demand savings apparent in the utility bills?

- Have the ESPC savings persisted?

- Are the ESPC cost savings apparent in the utility bills?

- Why is utility bill analysis seldom used for M\&V in ESPC projects?

— What are best practices for $\mathrm{M} \& \mathrm{~V}$, based on experience?

— What are the implications for agencies trying to reconcile ESPC savings and utility bills?

\subsection{Fort Polk ESPC Project}

In 1995 - 1996, Fort Polk used an ESPC to complete a major energy retrofit of its family housing units. An energy services company (ESCO) converted space conditioning equipment in all 4003 of its family housing units to geothermal heat pumps (GHPs). Original equipment consisted of air-source heat pumps with electric water heaters in $81 \%$ of the residences, and gas furnace/central air conditioner combinations with gas water heaters in the remaining 19\%. All of the gas water heaters were replaced with electric water heaters, and in the majority of residences, a desuperheater was installed with the GHP to supplement the heating elements in the water heater. Other ECMs such as compact fluorescent lighting, low-flow shower heads, and some insulation upgrades were installed at the same time.

\subsection{ORNL's 1998 Evaluation of the Fort Polk Project}

A detailed evaluation of the project, published in 1998, was carried out by a team of Oak Ridge National Laboratory (ORNL) researchers led by the authors (Hughes and Shonder 1998). For the evaluation, the team collected data on electricity use at 15-minute intervals in family housing for about one year before and one year after the retrofits (the periods are approximate because of varying construction schedules in the different housing areas). Based on this data, we estimated that in a typical meteorological year (TMY), the project would result in annual savings of 25.8 million $\mathrm{kWh}$, and that summer peak electrical demand in family housing would be reduced by an estimated 7.55 MW. These savings correspond respectively to $14 \%$ of the total post-wide pre-retrofit electricity use and $18 \%$ of post-wide summer peak demand. 


\subsection{Data Available for This Case Study}

There are three main sources of data on Fort Polk's electrical energy consumption: utility bills based on utility-maintained meters, Army-maintained submeters for the housing areas, and the metering equipment installed by ORNL for the original evaluation and reactivated by ORNL recently to investigate savings persistence.

The authors obtained records of Fort Polk's electricity bills for the 121-month period from June 1993 to June 2003. Excluding the 18-month construction period, the data set includes 21 months of pre-retrofit data (June 1993 - February 1995) and 82 months of post-retrofit data (September 1996 - June 2003). In addition to cost information, the monthly bills provide the electricity consumption in $\mathrm{kWh}$ and the monthly 15 -minute peak electrical demand in $\mathrm{kW}$. The serving utility maintains the electric meters and reads them remotely on the first day of each month; therefore the billing periods correspond to the actual number of days per month. The utility bills reflect all of the electricity used at Fort Polk for both housing and non-housing loads.

Fort Polk actually receives two monthly utility bills, one each for the North Fort and South Fort areas. In this report, the Fort Polk "totals" we refer to mean the sums of North Fort and South Fort bills.

Fort Polk maintains submeters on electrical distribution feeders that supply energy to the family housing areas. Data were collected manually from these meters monthly by Fort Polk personnel throughout the 121-month period from June 1993 to June 2003.

In 1995, ORNL installed equipment on the housing feeder submeters to collect electricity use data at 15-minute intervals. Use of this equipment was discontinued after data needs to support the original evaluation were satisfied. However, about 7 years later ORNL was able to resume collection of 15-minute-interval data on 4 feeders to support an investigation of savings persistence. During both the original and recent data collection periods, ambient temperature and humidity measurements were also made at 15-minute intervals at four locations across the post.

The ESPC project reduced use of both electricity and natural gas, but most of the savings by far were associated with electricity. This study focuses on electricity for the sake of simplicity and because all issues of interest can be addressed in the context of electricity.

From a National Oceanic and Atmospheric Administration (NOAA) web site, we obtained daily high and low temperatures at Fort Polk for the 121-month period from which we generated base- $65^{\circ} \mathrm{F}$ heating and cooling degree days for each month. Missing temperatures (about 150 out of 3682 days) were filled with data from our own monitoring equipment at the site or with NOAA data from Lufkin, Texas, which is about 50 miles west of Fort Polk.

Lufkin is the closest city to Fort Polk for which TMY data is available. Based on thirty years of observations, TMY files provide hourly data on ambient wet-bulb and dry-bulb temperatures, wind speed and direction, and other meteorological phenomena for a typical year at the site. These files drive building energy analysis programs such as TRNSYS, DOE-2, BLAST and EnergyPlus. In this study we used the Lufkin TMY data to normalize electricity use and demand to typical weather values. 


\subsection{Resolution of Electricity Use Savings from Utility Bill Analysis}

For this study, the authors conducted a utility bill analysis following generally accepted practices (ASHRAE 2002) to determine whether the reduction in electricity use caused by the ESPC project is apparent in the utility bills. (A detailed description of the analysis is provided in Appendix A).

Analysis of utility bills for all of Fort Polk for about one year before and one year after the retrofit yielded an estimate of savings in a TMY of 24.3 million $\mathrm{kWh}$, with a $95 \%$ confidence interval of \pm 4.0 million $\mathrm{kWh}$. This result confirms the estimates of electricity savings published in the original evaluation of the Fort Polk project (Hughes and Shonder 1998).

In the original study, we based our estimate of electricity savings on 15-minute-interval recordings from submeters on the electric distribution feeders serving the housing areas for about one year before and one year after the retrofit. That data indicated annual electricity savings from the retrofit as 25.8 million $\mathrm{kWh}$ in a typical year.

One can presume that the 25.8 million $\mathrm{kWh}$ is the true mean of savings, because this value is based on electricity consumption data for the housing areas only (about 80 million $\mathrm{kWh} / \mathrm{yr}$ before the retrofit), rather than on the total Fort Polk pre-retrofit electricity consumption of roughly 190 million $\mathrm{kWh}$ per year. The difference of 1.5 million $\mathrm{kWh}$ between the means of the two estimates could be explained by an increase of only $0.55 \%$ per year in the 110 million $\mathrm{kWh}$ per year of non-housing electricity use over the 2.5 years between the mid-points of the pre- and post-retrofit periods.

Nevertheless, the mean savings value of 24.3 million $\mathrm{kWh}$ is used in this report because it is derived directly from the regression equations for the utility bill analysis, and we use the regression analysis to illustrate important points.

Figures 1 and 2 graph some of the data for the utility bill analysis. Figure 1 displays actual monthly $\mathrm{kWh}$ from the utility bills for June 1993 through June 2003. The bar graph shows that energy use peaks in the summer months, falls to a minimum in the shoulder months, and rises to a lower peak during the winter months. The highest peaks in the post-retrofit period are lower than those in the pre-retrofit and construction periods, but beyond this, not much information can be discerned from the graph.

A clearer picture of the trend in electricity usage is obtained in Figure 2, which shows weather-normalized data, with each bar representing the annual electricity use for the 12month period ending with the plotted month. In this graph the 24.3 million $\mathrm{kWh}$ annual savings attributable to the ESPC project is clearly visible. Beginning in the construction period annual consumption began to drop, and then was relatively stable for the next 24 months. In August 1998 consumption began to rise, then fell again, but in July 2000 began a steady climb, which continued until February 2003. Section 3.6 of this report discusses this increase in consumption, along with analysis results indicating that the Fort Polk ESPC project is continuing to generate the expected savings. 


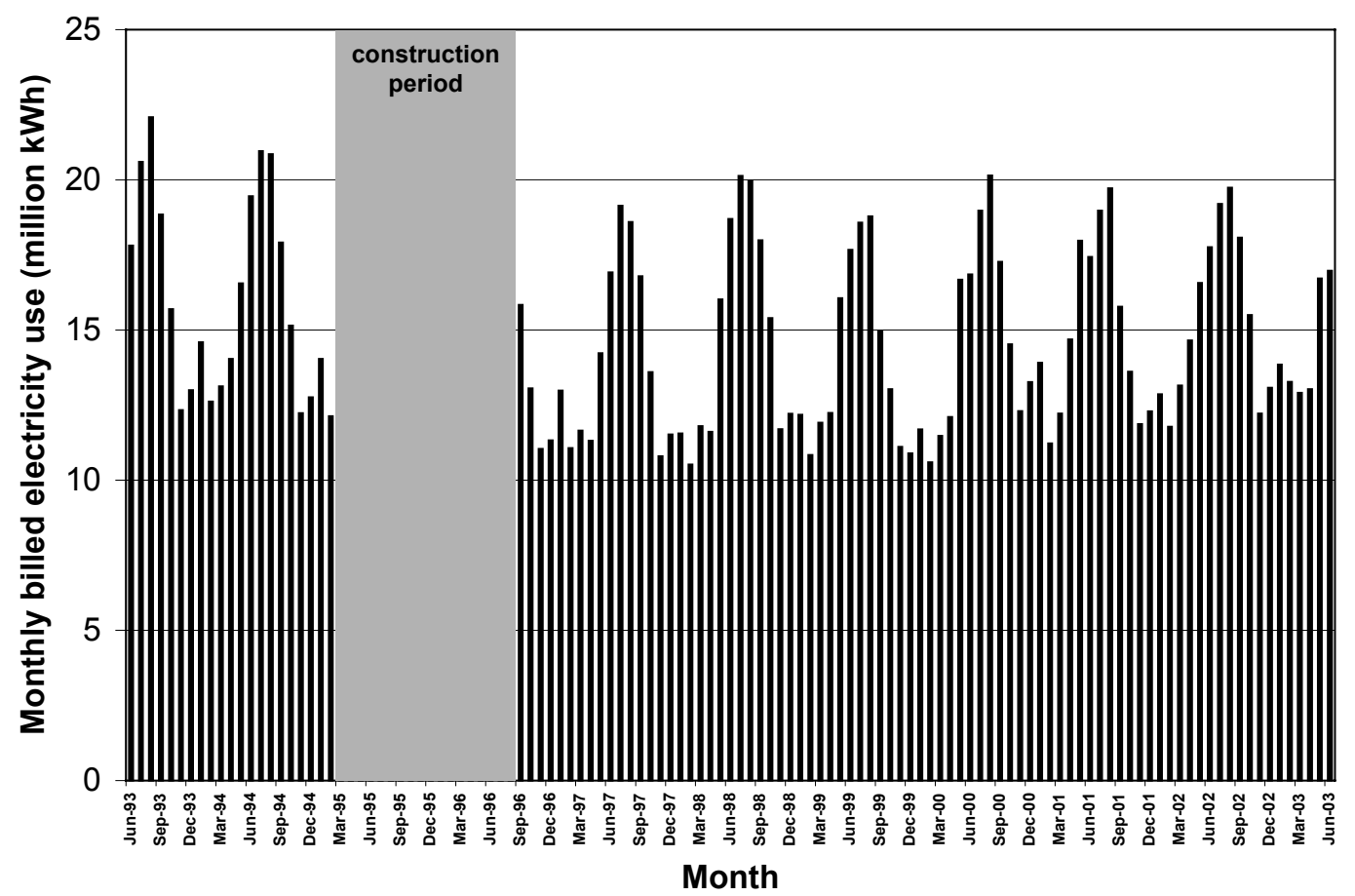

Figure 1. Total billed electricity use for Fort Polk, June 1993 - June 2003. Usage peaks are lower after the construction period than before, but we can conclude very little other than that from this graph.

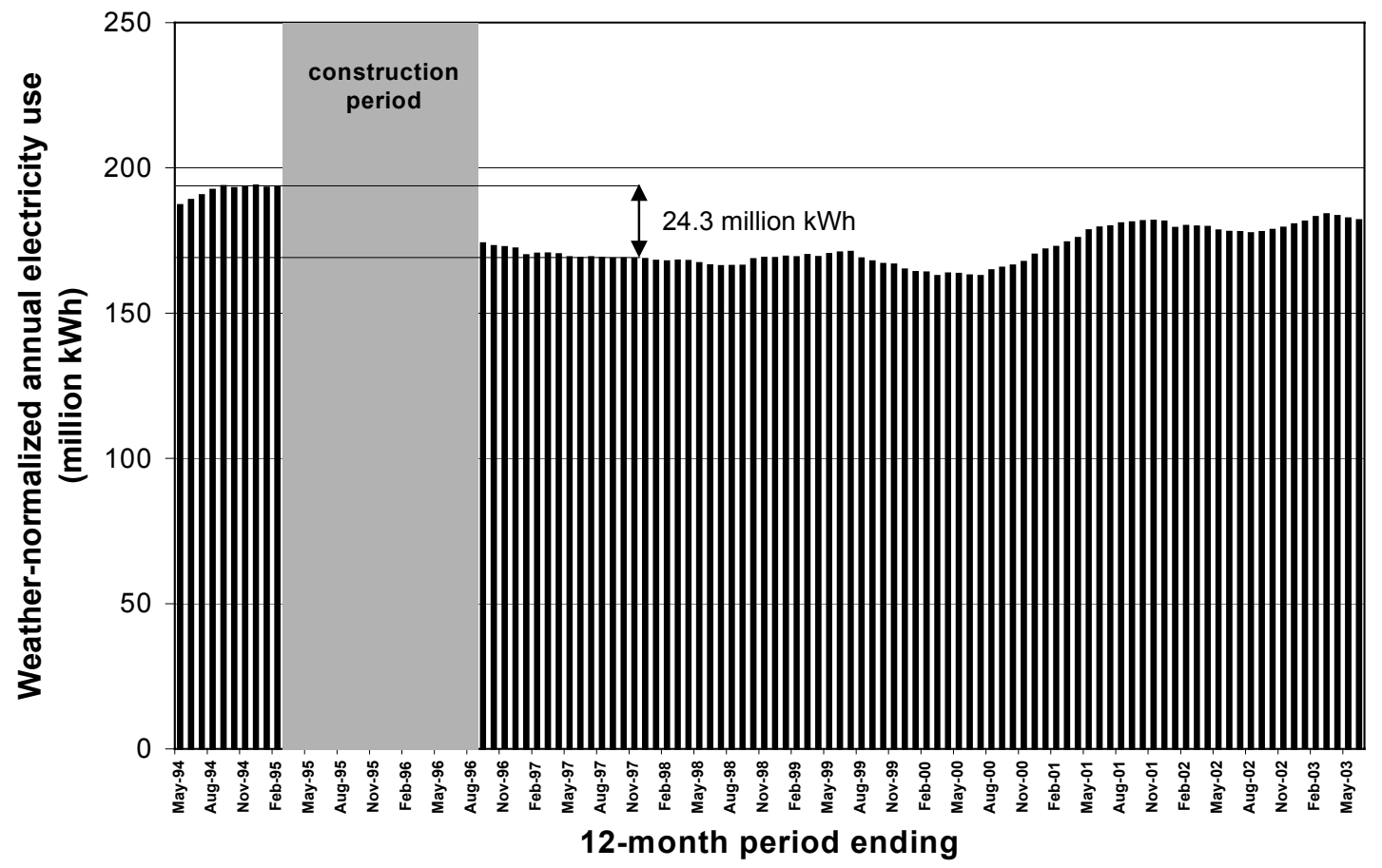

Figure 2. Fort Polk's total billed electricity use, normalized to TMY. Each bar represents weather-normalized annual electricity use for the 12-month period ending with the graphed month. 


\subsection{Resolution of Reduced Peak Demand from Utility Bill Analysis}

Our analysis showed that reductions in peak electricity demand caused by the ESPC project, as well as usage reductions, are apparent in the utility bills. (See Appendix B for a detailed description of the demand reduction analysis.) Based on the utility bills for all of Fort Polk, a demand reduction of 7.27 MW from the total Fort Polk peak demand of 42 MW is estimated, with a $95 \%$ confidence interval of $\pm 3.1 \mathrm{MW}$. Again, this confirms our estimate of $7.55 \mathrm{MW}$ in the original evaluation, which was based on data from the housing submeters only. The $0.25-\mathrm{MW}$ difference in mean values of the two estimates could easily be explained by an annual increase of only $0.42 \%$ in the roughly $24.4 \mathrm{MW}$ of non-housing electrical demand over the 2.5 years between the mid-points of the pre- and post-retrofit periods.

Although we presume that $7.55 \mathrm{MW}$ is the true mean of savings, the value of $7.27 \mathrm{MW}$ is used in this report so the regression analysis can be used to illustrate important points.

The trend in peak demand can be seen in Figure 3, which plots the weather-normalized total Fort Polk peak demand. Each bar represents the highest monthly peak demand (always in summer) from the 12-month period ending with the plotted month. The project's $7.27-\mathrm{MW}$ reduction is clearly visible, but this graph gives us no information about, for example, the increase in peak demand in 2001.

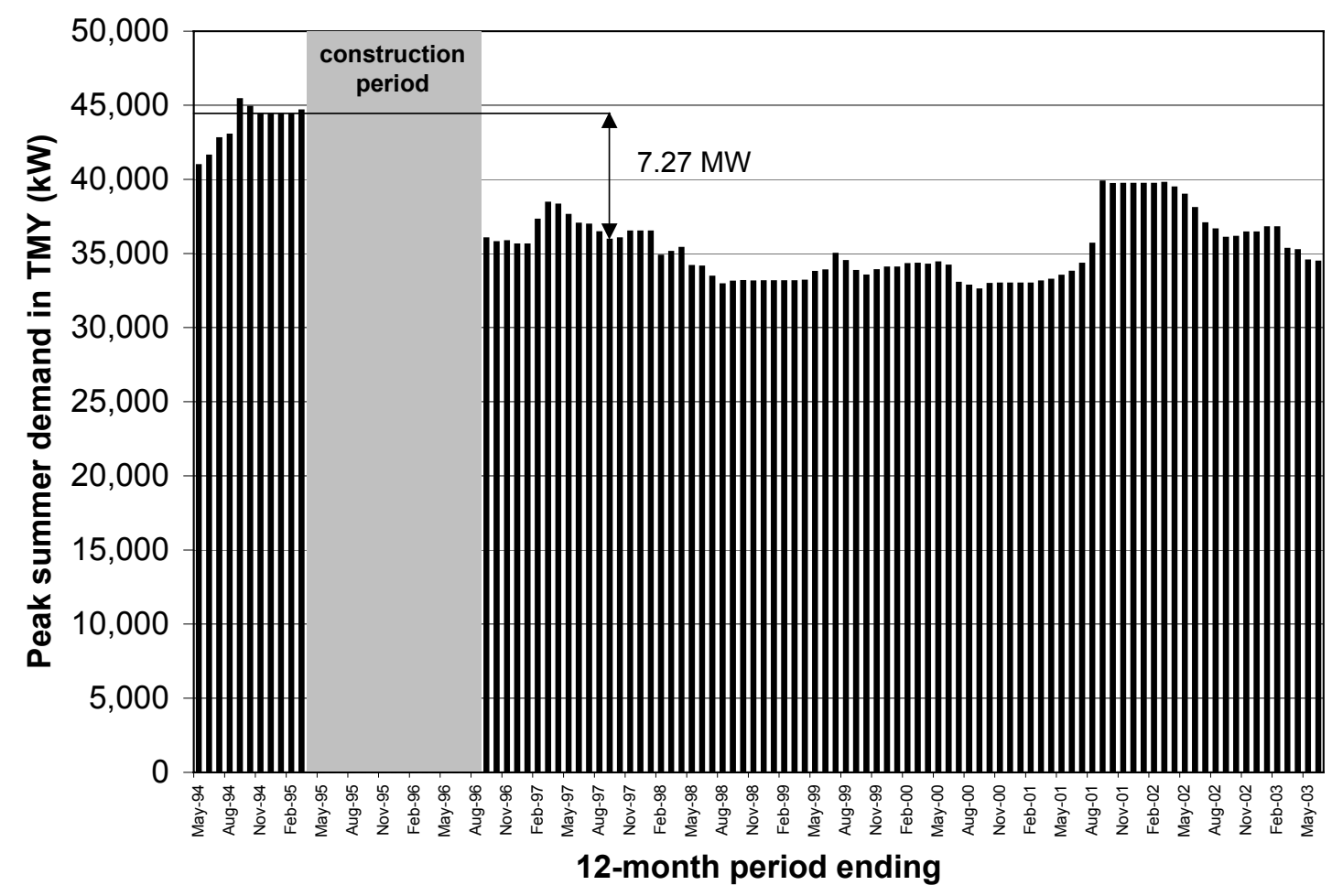

Figure 3. Weather-normalized Fort Polk peak demand. Each column shows highest peak demand (always in summer) from the 12-month period ending with the plotted month. 


\subsection{Persistence of Savings}

The ECMs installed in 1995 - 1996 had a definite impact on electricity use and demand at Fort Polk, shown clearly in figures 2 and 3. But starting in about August of 2000, overall Fort Polk electricity use began a steady rise, and by June 2003 the weathernormalized annual consumption was halfway back to pre-retrofit levels. This section addresses the question of whether the ESPC project savings are falling short by $50 \%$ or post-wide loads have simply grown. Our analysis of submetered data from electricity feeders to Fort Polk family housing indicates that electricity use in those areas has increased very little since the ESPC project was completed. Our analysis is reviewed below and discussed in detail in Appendix C.

The submeters on the feeders to the housing areas are read manually by Army staff once per month to track family housing electricity use. Figure 4 presents the sum of these meter readings for the same period for which we analyzed Fort Polk's utility bills, June 1993 to June 2003. As with electricity use for the entire facility, the raw data is not very informative.

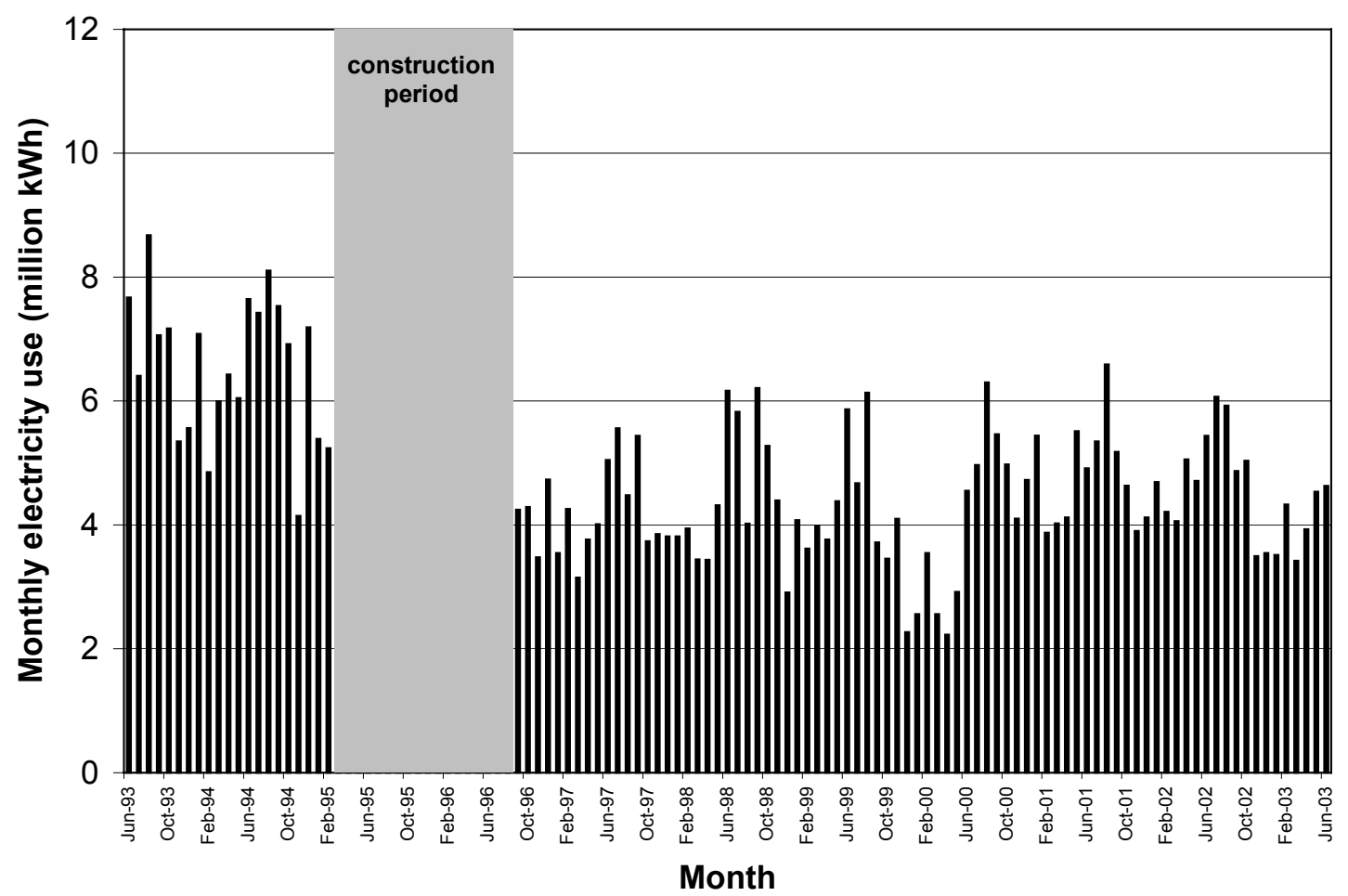

Figure 4. Monthly sums of readings from the 16 electricity submeters in the family housing areas.

In our original study of the Fort Polk retrofit project, we attached data loggers to 14 of the 16 family housing electricity submeters in order to read them electronically at 15 -minute intervals. All 14 feeders exhibited electricity use patterns characteristic of pure housing 
loads. In July 2003, we restarted automated data collection on 11 of our original 14 feeders. We were able to verify proper operation of the automated data collection equipment on four feeders (Feeders 3, 4, 6, and 16) and that the loads on these feeders were from housing only. The data from the four feeders for both $1996-1997$ and $2003-$ 2004 are plotted in Figure 5. These feeders represent about 12\% of the 5 million square feet of family housing at Fort Polk, a sufficient sample size for representing all housing on the post.
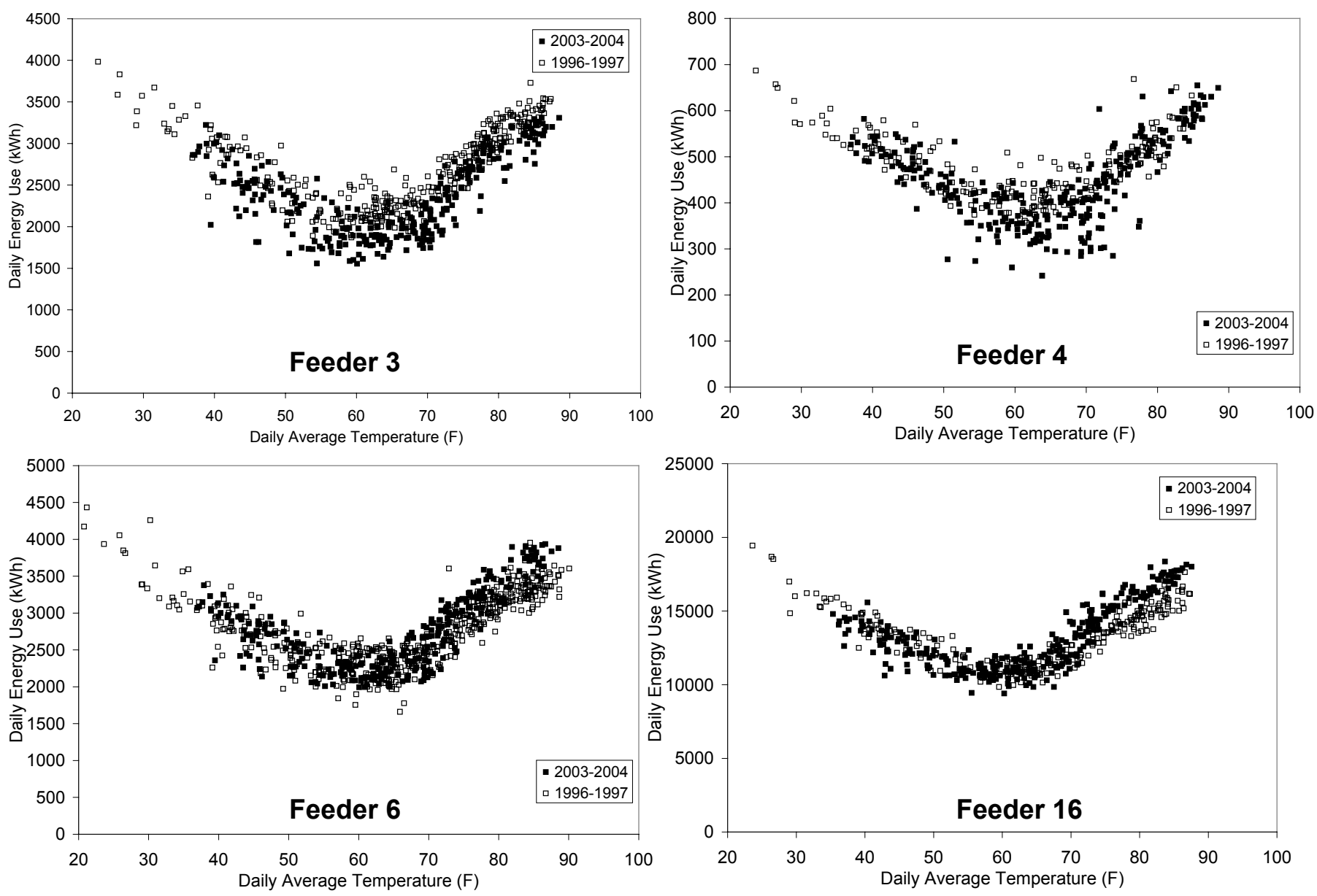

Figure 5. Electricity use on four submetered feeders to Fort Polk family housing appears to have changed very little, based on comparison of 1996-1997 and 2003 - 2004 data sets.

For each of the four feeders with usable data, we fitted daily electricity use data from 1996-1997 and 2003-2004 to a five-parameter function of daily average temperature, using the technique described in our original evaluation of the Fort Polk project (Hughes and Shonder 1998). This regression analysis allowed us to predict annual energy use for a typical year. If there have been no increases in energy use, then the TMY predictions 
from the two data sets should be roughly the same. Table 1 shows the results of the regression analysis of 1996-1997 and 2003-2004 electricity use data for the four feeders.

The analysis indicates that energy use has decreased on some of the feeders and increased on others. Some of the changes are undoubtedly due to changes in occupancy, about which we have no information. Overall, energy use for the four feeders has increased by $2.2 \%$ over 7 years. This is an annual rate of increase of just $0.31 \%$. Based on this analysis of a large sample of Fort Polk's housing, we conclude that there have been only small increases in electricity use in Fort Polk's family housing since the retrofits were installed. These increases are smaller than housing load growth due to plug load increases that we predicted in the 1998 evaluation, based on national averages at the time for plug load growth.

Table 1. Annual electricity use predicted for a TMY by regression analysis of 1996-1997 and 20032004 electricity use data for four submetered Fort Polk family housing feeders.

\begin{tabular}{cccc}
\hline Feeder & $\begin{array}{c}\text { TMY energy use } \\
\text { based on 1996-1997 } \\
\text { data }(\mathrm{kWh})\end{array}$ & $\begin{array}{c}\text { TMY energy use } \\
\text { based on } 2003-2004 \text { data } \\
(\mathrm{kWh})\end{array}$ & $\begin{array}{c}\text { Percentage } \\
\text { change }\end{array}$ \\
\hline 3 & 977,428 & $883,000 \pm 9,400$ & $-9.7 \%$ \\
4 & 176,601 & $167,000 \pm 2,100$ & $-5.5 \%$ \\
6 & 999,035 & $1,038,000 \pm 9,400$ & $3.9 \%$ \\
16 & $4,763,891$ & $4,980,000 \pm 27,000$ & $4.6 \%$ \\
Total & $6,916,955$ & $7,070,000 \pm 39,000$ & $2.2 \%$ \\
\hline
\end{tabular}

This indication that savings from the retrofit have persisted over time, along with our confidence in our analysis of energy use immediately before and after the retrofit, support the validity of using the mean values of 24.3 million $\mathrm{kWh}$ (usage) and 7.27 MW (demand) for ESPC project savings in a TMY for all analysis years in the rest of this report. Using these values is also consistent with accepted ESPC practice in that the small increase in energy use indicated by the analysis results in Table 1, which is from plug load growth, is not held against the ESCO, but is regarded as the facility's responsibility.

\subsection{Resolution of ESPC Cost Savings from Utility Bill Analysis}

This study has shown that electricity use and demand savings from the ESPC project are apparent in Fort Polk's weather-normalized utility bills, when comparing periods immediately before and after the retrofit. Analysis of submetered data also indicates that these savings appear to have held up over the 7 years since the retrofit. We also analyzed Fort Polk's utility bills to estimate true cost savings attributable to the ESPC project. The analysis was structured to value the savings at their true marginal rates, in accordance with the electricity rate structures. The utility bills capture the net effect of all factors influencing electricity use and demand, including the ESPC project. Total billed Fort Polk electricity costs are shown in Figure 6. 
Actual monthly total billed $\mathrm{kWh}$ and $\mathrm{kW}$ define the energy baseline for this analysis. The electricity cost baseline was defined mathematically by implementing the electricity rate structures in a spreadsheet and verified by entering the actual monthly $\mathrm{kWh}$ and $\mathrm{kW}$ values to reproduce the billed electricity costs.

Adding $\mathrm{kWh}$ and $\mathrm{kW}$ savings to billed values yielded monthly $\mathrm{kWh}$ and $\mathrm{kW}$ that would have been billed if the ESPC project had never been implemented. These values were run through the electric rate schedules to calculate electricity costs that Fort Polk would have incurred if the ESPC project had not been done. Subtracting the actual billed costs yields the cost savings attributable to the ESPC project.

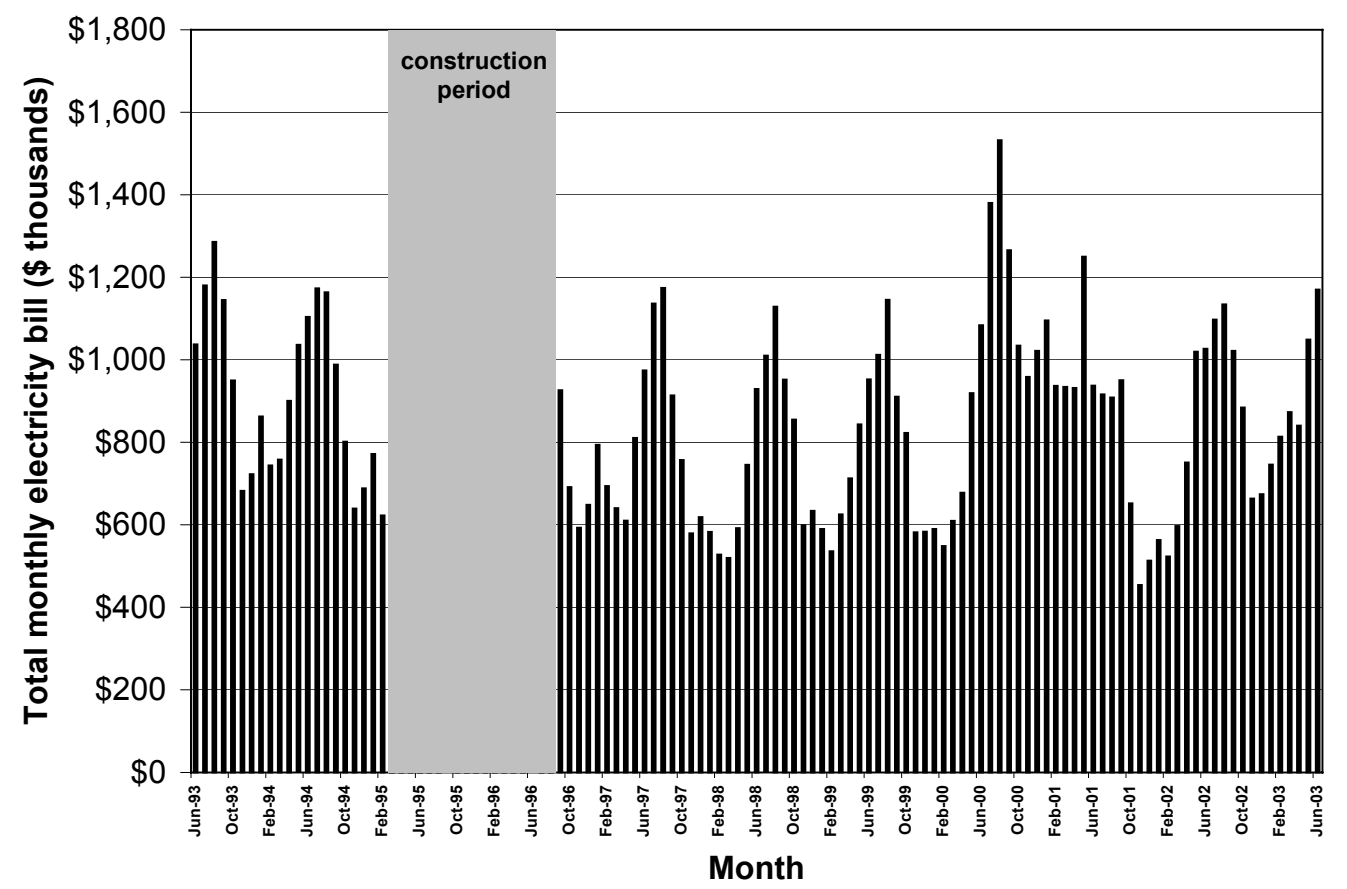

Figure 6. Total billed Fort Polk electricity costs, June 1993 through June 2003.

The relationships used to calculate pre- and post-retrofit $\mathrm{kWh}$ and $\mathrm{kW}$ from weather data, and to arrive at savings by subtracting post-retrofit from pre-retrofit values, are described in detail in Appendices A and B. Actual weather data (not TMY data) for the months during the analysis period were used to yield realistic energy and demand values, and actual electricity rate structures in effect during the period were the basis for the cost estimates.

The monthly electricity cost savings to Fort Polk resulting from the ESPC, as estimated from the analysis described above, are presented in Figure 7 . These monthly values are the basis for the annual cost savings presented in Figure 8, where the bars represent the sum of cost savings for the year preceding (and including) the plotted month. The first annual savings is shown in the first month when all 12 months in the period represented occurred after the ESPC project was fully installed. The average annual electricity cost savings from the ESPC over the time interval shown in Figure 8 is $\$ 1,450,000$. Figure 9 shows the actual total annual electricity cost along with total electricity costs that would have been incurred if the ESPC project had never been implemented. 


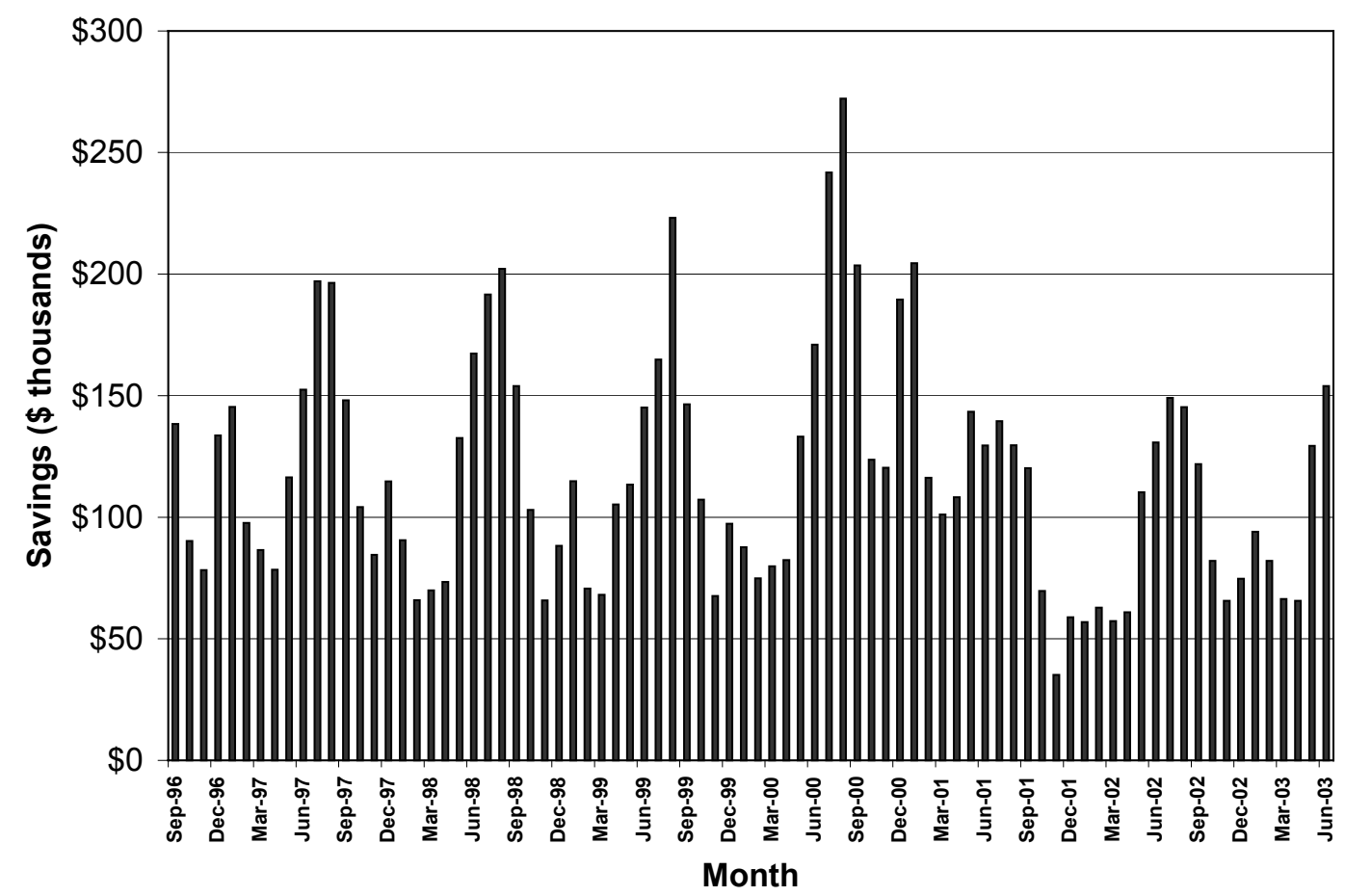

Figure 7. Electricity cost savings to Fort Polk resulting from the ESPC project, as estimated by analyzing Fort Polk's utility bills.

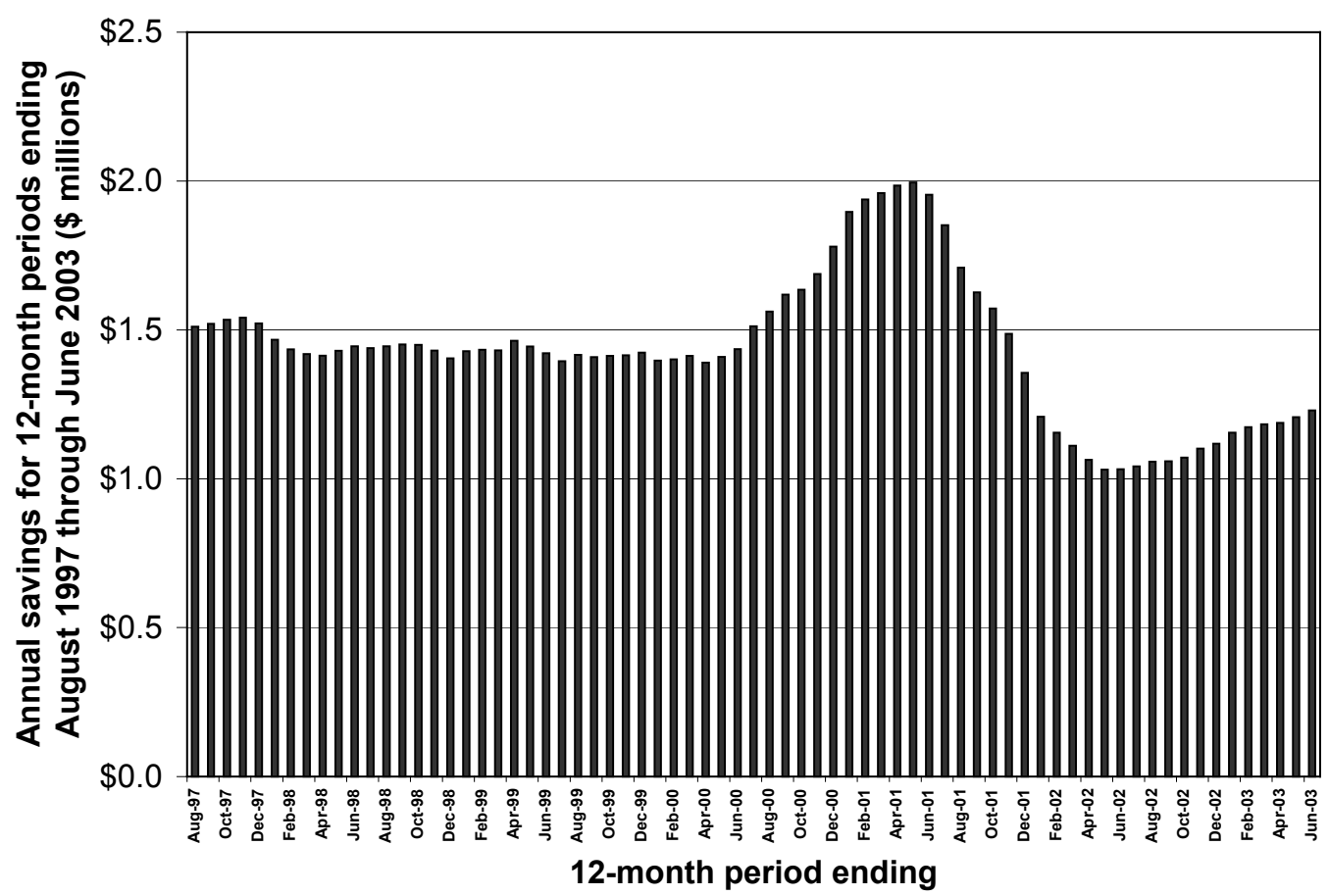

Figure 8. Annual cost savings to Fort Polk from the ESPC project expressed as the sum of cost savings for the 12-month periods ending with the plotted months. 


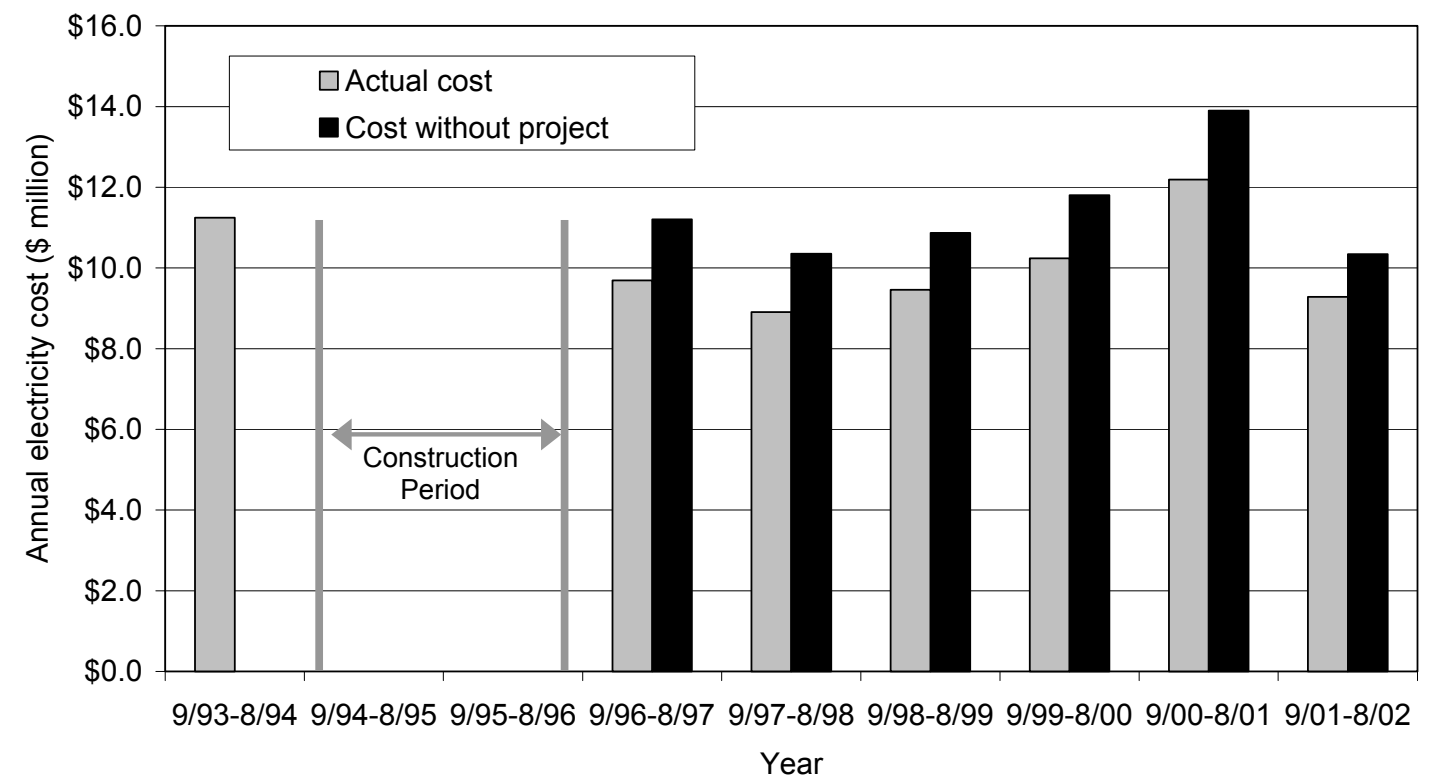

Figure 9. Actual total annual Fort Polk electricity costs, and costs that would have been incurred if the ESPC project had never been implemented, before and after the retrofit.

\section{M\&V Lessons Learned}

The Fort Polk project was implemented relatively early in the history of federal ESPC activity, before the advent of standardized and streamlined ESPC umbrella contracts in 1998. Since then, federal buildings have been improved with $\$ 1.5$ billion worth of ESPC investments, and $\mathrm{M} \& \mathrm{~V}$ practices have been significantly refined through experience. The $M \& V$ guidelines used by today's performance contracting industry, such as IPMVP, FEMP M\&V Guidelines, and ASHRAE Guideline 14, were all developed and/or refined between 1998 and 2002.

Today agencies rarely depend on utility bill analysis (referred to as M\&V Option C by IPMVP and FEMP), even if the project's size would allow the savings to be discerned in the utility bills for the period immediately after installation. Federal ESPCs are long-term contracts, 15 years on average, and $M \& V$ is intended to verify savings annually over the entire period, not just immediately after installation. This section highlights some of the $M \& V$ best practices developed over the years that enable savings to be verified at modest expense, to an acceptable degree of certainty, and without allocating unreasonable risks to the project provider, which would inevitably burden projects with premium pricing and financing costs as compensation for bearing those risks. 


\subsection{Risk and Responsibility Matrix}

Delivery order awards under the DOE Super ESPC program include a Risk and Responsibility Matrix that documents the assignment of risks and responsibilities to the ESCO and the government in the form of mutually agreeable assumptions. The matrix extends beyond just the $M \& V$ approach used to verify guaranteed savings.

Note that there are distinctive meanings assigned to categories of savings in ESPCs, both in common usage and for the purposes of this study:

- Estimated savings - The ESCO's prediction of the annual savings the project will generate, documented in the financial schedules of the delivery order (in terms of both energy units and dollars).

- Guaranteed savings - The contractually guaranteed annual savings (in dollars) that the project must deliver, which must exceed annual payments to the ESCO.

- Actual savings - For the purposes of this study, savings calculated based on analysis of actual data from monthly utility bills, monthly submeter readings, or 15-minute-interval data loggers (energy units or dollars).

- Contracted savings - Savings calculated for the annual M\&V report to determine whether the guarantee has been met using the algorithms, stipulations, and assumptions agreed upon in the contract and the M\&V plan (energy units or dollars).

The goal in assigning M\&V-related risks and responsibilities is to achieve a costeffective ESPC project where the ESCO can be held accountable for contracted savings equaling or exceeding the guarantee each year, and where contracted and actual cost savings remain reasonably proximate to each other annually and converge over the contract term, ensuring that savings exceed payments. Highlighted here are several common, and indeed recommended, $M \& V$-related risk and responsibility assignments, which nonetheless potentially de-couple contracted and actual cost savings in any given year.

It is important that any mutually agreed upon assumptions be carefully selected. Risk and responsibility assignments related to weather, energy loads, energy price escalation, and ECM performance are highlighted in the following sections.

\subsection{ECM Performance}

Directly or through use of subcontractors, the ESCO designs the ECM application, selects the equipment, installs the ECM, and commissions the ECM. Therefore, the ESCO is in a position to bear the risk of fixed ECM prices and guaranteed performance, and is assigned these responsibilities under the contract. How does assigning the risk and responsibility for ECM performance to the ESCO relate to the electric utility bill? Essentially, the ESCO's equipment is expected to perform so that specified levels of 
electricity use and demand savings are achieved in comparison to the pre-project baseline under the mutually agreed upon stipulations for weather and energy load.

\subsection{Weather}

Neither party can control the weather, so the government and ESCO generally agree (stipulate) that typical weather (TMY data) will be used for the purposes of calculating contracted electricity use savings in $\mathrm{kWh}$ and demand savings in $\mathrm{kW}$ (or savings of other energy sources, e.g., natural gas). This agreement clarifies the ESCO's performance responsibilities in a practical manner, rather than forcing the private-sector partner to shoulder an unmanageable risk that would result in premium pricing and financing costs.

The consequence of using typical weather in calculating contracted savings is that contracted and actual savings may differ in any given year. This is illustrated using our data and analysis on Fort Polk in tables 2 and 3. Shown are savings for a TMY and actual $\mathrm{kWh}$ and $\mathrm{kW}$ savings for the post-retrofit 12-month periods (September through the following August) from 1996-97 to 2001-02.

Tables 2 and 3 also present the guaranteed savings, the difference between the actual savings and the guaranteed savings, and the cumulative difference between actual and guaranteed savings. Typically an ESCO would guarantee only a fraction of the estimated energy and demand savings. In this case we assume guaranteed savings to be to be $95 \%$ of contracted savings.

Table 2.

Actual Fort Polk electricity use savings compared to contracted savings and guaranteed savings ${ }^{a}$

\begin{tabular}{|c|c|c|c|c|c|c|c|}
\hline & \multicolumn{7}{|c|}{ Annual electricity use savings (million $\mathrm{kWh}$ ) } \\
\hline Post-retrofit year $^{b}$ & $\begin{array}{c}\text { Typical } \\
\text { year }\end{array}$ & $\begin{array}{c}\text { 1996- } \\
97 \\
\end{array}$ & $\begin{array}{c}1997- \\
98 \\
\end{array}$ & $\begin{array}{c}1998- \\
99 \\
\end{array}$ & $\begin{array}{c}1999- \\
2000 \\
\end{array}$ & $\begin{array}{c}2000- \\
01 \\
\end{array}$ & $\begin{array}{c}2001- \\
02 \\
\end{array}$ \\
\hline Actual savings (actual weather) & & 23.6 & 26.1 & 25.3 & 24.6 & 25.3 & 24.5 \\
\hline Contracted savings in $\mathrm{TMY}^{c}$ & 24.3 & 24.3 & 24.3 & 24.3 & 24.3 & 24.3 & 24.3 \\
\hline Actual minus contracted & & $(0.7)$ & 1.8 & 1.0 & 0.3 & 1.0 & 0.2 \\
\hline Cumulative actual minus contracted & & $(0.7)$ & 1.1 & 2.1 & 2.4 & 3.4 & 3.6 \\
\hline Guaranteed savings $^{d}$ & 23.1 & 23.1 & 23.1 & 23.1 & 23.1 & 23.1 & 23.1 \\
\hline Actual minus guaranteed & & 0.5 & 3 & 1.3 & 0.6 & 0.4 & $(0.8)$ \\
\hline Cumulative actual minus guaranteed & & 0.5 & 3.5 & 4.8 & 5.4 & 5.8 & 5 \\
\hline $\begin{array}{l}{ }^{a} \text { Contracted and guaranteed savings } \\
\text { adjusted to eliminate the effects of the de } \\
{ }^{b} \text { Twelve-month periods September } \mathrm{t} \\
{ }^{c} \text { For this illustration, contracted savi } \\
\text { about one year before and one year after } \\
{ }^{d} \text { Guaranteed savings for this illustrat }\end{array}$ & $\begin{array}{l}\text { pothetical } \\
\text { on of som } \\
\text { August. } \\
\text { the annua } \\
\text { rofit (see } \\
95 \% \text { of ce }\end{array}$ & $\begin{array}{l}\text { ut calcul } \\
\text { family ho } \\
\text { savings v } \\
\text { ction } 3.4 \text { ) } \\
\text { tracted }\end{array}$ & $\begin{array}{l}\text { ed based } \\
\text { sing units } \\
\text { ue detern }\end{array}$ & actual d & ysis of & ty bills & \\
\hline
\end{tabular}

The energy savings for a TMY at the site have been calculated as 24.3 million $\mathrm{kWh}$, which for this illustration is also the contracted savings. Note, however, that the actual savings differ from contracted savings because of weather variation in any given year. 
Actual savings also differ from contracted savings because about 10\% of Fort Polk's family housing was demolished beginning in 1998, but all of the analysis and results in this section correct for the demolitions, and savings are calculated as if there had been no housing demolitions. Table 2 shows that the average annual actual savings over the 19962002 period were 24.9 million $\mathrm{kWh}$, slightly (about 2.5\%) higher than the contracted savings for a TMY. In no year were the actual savings more than $8 \%$ higher or $3 \%$ lower than the contracted savings.

A similar result holds for peak summer demand savings, shown in Table 3. We have already shown that in a TMY, the peak summer demand savings would be $7.27 \mathrm{MW}$, which for this illustration equals the contracted demand savings. In the post-retrofit period, actual summer peak demand savings is sometimes higher and sometimes lower than the contracted amount depending on weather conditions, but the variation is never more than 18\% higher or lower than the contracted amount. From 1996 to 2002, the average actual summer peak demand savings is $7.71 \mathrm{MW}$, about $6 \%$ higher than the contracted amount.

Table 3. Actual Fort Polk electricity demand savings compared to contracted savings and guaranteed savings ${ }^{a}$

\begin{tabular}{|c|c|c|c|c|c|c|c|}
\hline & \multicolumn{7}{|c|}{ Summer peak electrical demand savings (peak month MW) } \\
\hline Post-retrofit year ${ }^{b}$ & $\begin{array}{c}\text { Typical } \\
\text { year }\end{array}$ & $\begin{array}{c}\text { 1996- } \\
97\end{array}$ & $\begin{array}{c}\text { 1997- } \\
98\end{array}$ & $\begin{array}{c}1998- \\
99\end{array}$ & $\begin{array}{l}1999- \\
2000\end{array}$ & $\begin{array}{c}2000- \\
01\end{array}$ & $\begin{array}{c}2001- \\
02\end{array}$ \\
\hline Actual savings (actual weather) & & 6.45 & 7.89 & 7.89 & 8.61 & 8.61 & 6.81 \\
\hline Contracted savings in $\mathrm{TMY}^{c}$ & 7.27 & 7.27 & 7.27 & 7.27 & 7.27 & 7.27 & 7.27 \\
\hline Actual minus contracted & & $(0.82)$ & 0.62 & 0.62 & 1.34 & 1.34 & $(0.46)$ \\
\hline Cumulative actual minus contracted & & $(0.82)$ & $(0.20)$ & 0.42 & 1.76 & 3.10 & 2.64 \\
\hline Guaranteed savings $^{d}$ & 6.91 & 6.91 & 6.91 & 6.91 & 6.91 & 6.91 & 6.91 \\
\hline Actual minus guaranteed & & $(0.46)$ & 0.98 & 0.72 & 1.38 & 1.38 & $(0.72)$ \\
\hline Cumulative actual minus guaranteed & & $(0.46)$ & 0.53 & 1.25 & 2.63 & 4.02 & 3.30 \\
\hline
\end{tabular}

\subsection{Energy Loads}

Generally the government controls how many hours per day a building is used, which is a prime contributor to energy load, so in a typical retrofit-isolation M\&V approach, operating hours are measured during baseline development, and a reasonable value is agreed on (stipulated) as the basis for calculating savings. In the case of Fort Polk family housing, in a utility bill M\&V approach where the "utility meter" in reality refers to only the submetering of electricity into the housing areas, the analogous stipulations might be housing occupancy rate or total population of the housing area, with some allowance for 
plug load growth over time. Using data from the actual post-wide utility meters for M\&V adds the complication of the non-housing loads.

Before the retrofit, family housing accounted for about $42 \%$ of the total post-wide electricity use of $\sim 190$ million kWh per year. Obviously, the ESCO cannot be held accountable for the growth in the $\sim 110$ million $\mathrm{kWh}$ per year of non-housing load at the post. But even in family housing, it would not be appropriate or cost-effective to hold the ESCO accountable for increases in energy use due to factors such as a changing occupancy rate and plug load growth.

Figure 10 helps us to visualize the magnitude of unaccounted for electric load variation that occurs at a large post like Fort Polk. The bars in Figure 10 show the weathernormalized total electricity use in $\mathrm{kWh}$ by year. For post-retrofit years, higher bars indicate the estimated total Fort Polk electricity use that would have occurred without the improvements implemented under the ESPC project. Note that the pre-retrofit energy use is comparable to the higher of the two 1996-97 post-retrofit bars, as would be expected, with the shorter 1996-97 bar representing the billed electricity use after the ESPC project was implemented.

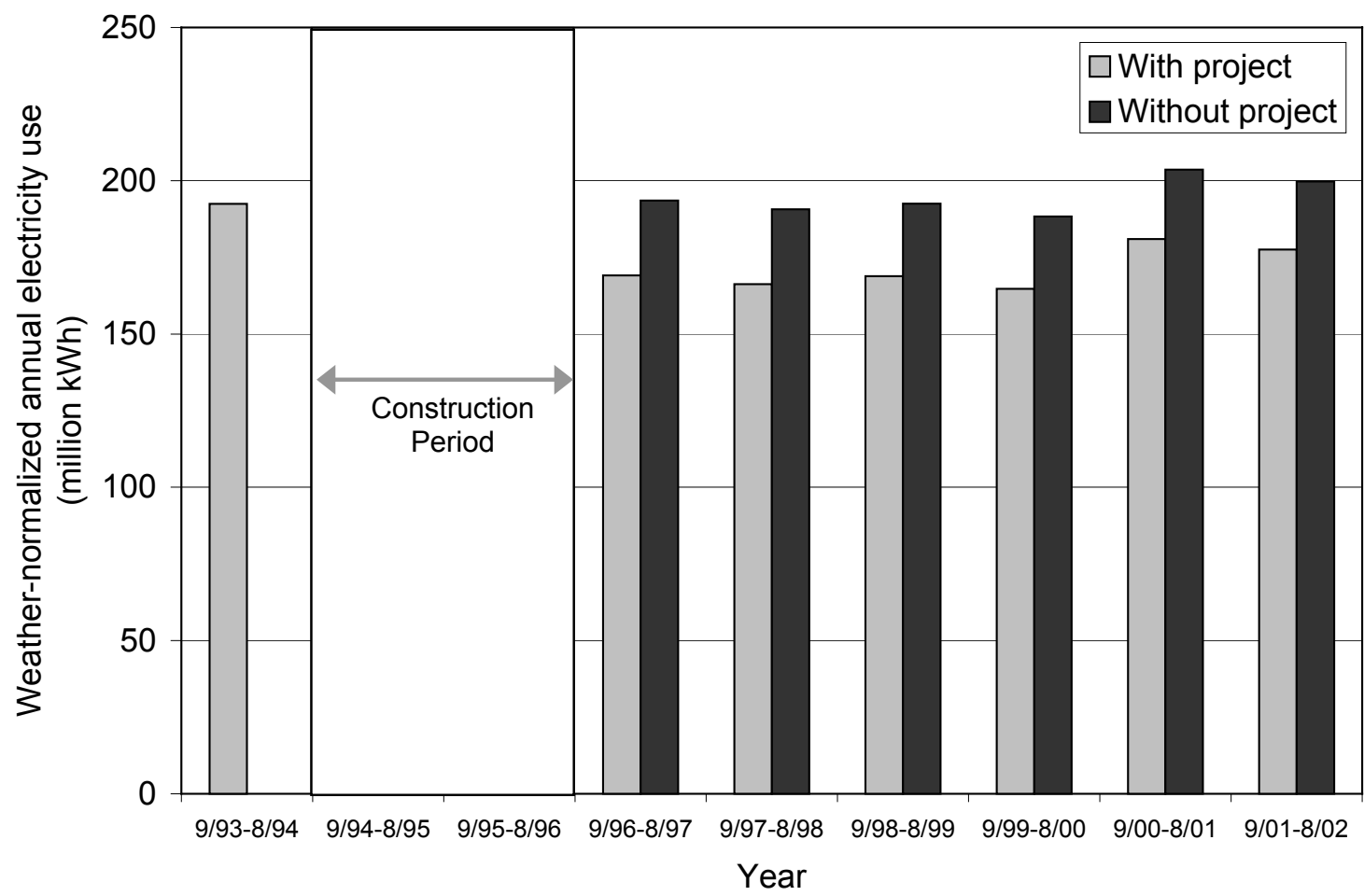

Figure 10. Weather-normalized actual total annual electricity use at Fort Polk compared to estimated post-retrofit total electricity use that would have occurred if the ESPC project had not been implemented. 
If post-retrofit electricity use were the same in all years, we might conclude that Fort Polk's troop levels and war fighting mission were stable and that new electric loads were offset by other load reductions, but they clearly are not. Compared to 1996-97, these loads not related to the ESPC project are 12 million kWh higher in 2000-2001 and 4 million kWh lower in 1999-2000. The post is fully responsible for these large variations in load, but without submetering or an energy monitoring/management system, there is no way to tell where the new load comes from. Furthermore, these large changes in load could have an impact on how the ESPC project's electricity reductions in use and demand are valued as cost savings.

\subsection{Energy Price Escalation}

It is common practice for the government and the ESCO to agree, for the purpose of calculating contracted cost savings, that current electricity rates will escalate at a constant rate. Like weather and load stipulations, these agreements are a practical way to clarify the ESCO's responsibilities but not burden the project with premium pricing and financing costs to pay the private-sector partner for bearing an unmanageable risk.

The experience at Fort Polk illustrates why agreement to use constant electricity price escalation factors is practical and common. During the 121-month period for which utility bills are available, Fort Polk was billed for electricity under four different rate structures. Within these different rate structures, in addition to the valuation of electricity usage and demand, is the fuel adjustment charge, which can vary from month to month with the price of the utility's power generation fuel and accounts for about $35 \%$ of Fort Polk's total electricity bill, on average.

Further, changes in the weather and Fort Polk's mission affect electric loads and the valuation of the ESPC project's savings, which is at the margin when processed through the actual rate structures. Obviously neither the ESCO nor Fort Polk can predict weather, mission, or electricity rates. If the ESCO were required to guarantee electricity cost savings based on whatever the weather, mission, or rates turned out to be, excessive costs for hedges or insurance would have to be built into the price of the project, and Fort Polk would end up paying them anyway.

Nevertheless, it is true that calculating contracted electricity cost savings based on typical weather and constant energy price escalation does mean that contracted savings and actual savings may differ in a year, as illustrated using data from Fort Polk in Table 4.

The table compares actual cost savings (actual weather and actual utility rate structures) with hypothetical contracted savings calculated based on TMY and electricity price escalation of $0.5 \%$ per year for 1996-97 through 2001-02. Actual cost savings are also compared to hypothetical guaranteed cost savings, which are based on $95 \%$ of energy and demand savings in a TMY, extrapolated to dollar savings using the rate structure in effect at the time of contract award.

The first row in Table 4 shows actual energy cost savings per year. We have previously shown that the annual savings in a typical year, based on the electricity rate that applied in the pre-retrofit period, is $\$ 1.55$ million. Now suppose Fort Polk and the ESCO agree to escalate these cost savings at $0.5 \%$ per year. The second row in Table 4 shows what the 
annual contracted savings would be through 2002. The third row shows the difference between actual savings and contracted savings. For the first three post-retrofit years, the contracted savings are higher than actual savings, but in 1999-2000 and again in 20002001, actual savings are higher than contracted savings. By the end of 2001, the cumulative net difference is zero. A drop in rates in 2001 brings actual savings below contracted savings, but presumably in the long run things will even out.

Table 4. Actual savings compared to contracted savings with $0.5 \%$ per year escalation and compared to guaranteed savings ${ }^{a}$

\begin{tabular}{|c|c|c|c|c|c|c|c|}
\hline \multirow[b]{2}{*}{ Post-retrofit year ${ }^{b}$} & \multicolumn{7}{|c|}{ Annual electricity use cost savings (\$ millions) } \\
\hline & $\begin{array}{l}\text { Typical } \\
\text { year }\end{array}$ & $\begin{array}{c}1996- \\
97\end{array}$ & $\begin{array}{c}1997- \\
98\end{array}$ & $\begin{array}{c}1998- \\
99\end{array}$ & $\begin{array}{l}1999- \\
2000\end{array}$ & $\begin{array}{c}2000- \\
01\end{array}$ & $\begin{array}{c}2001- \\
02\end{array}$ \\
\hline $\begin{array}{l}\text { Actual savings (actual weather and } \\
\text { actual rates) }\end{array}$ & & 1.51 & 1.44 & 1.46 & 1.62 & 1.84 & 1.16 \\
\hline $\begin{array}{l}\text { Contracted savings }{ }^{c} \text { (TMY and price } \\
\text { escalation of } 0.5 \% \text { per year) }\end{array}$ & 1.55 & 1.56 & 1.57 & 1.57 & 1.58 & 1.59 & 1.60 \\
\hline Actual minus contracted & & $(0.05)$ & $(0.13)$ & $(0.11)$ & 0.04 & 0.25 & $(0.44)$ \\
\hline Cumulative actual minus contracted & & $(0.05)$ & $(0.17)$ & $(0.29)$ & $(0.25)$ & 0.00 & $(0.43)$ \\
\hline Guaranteed savings $^{d}$ (ESCO payment) & 1.47 & 1.48 & 1.48 & 1.49 & 1.50 & 1.51 & 1.51 \\
\hline Actual savings minus ESCO payment & & 0.03 & $(0.04)$ & $(0.03)$ & 0.12 & 0.33 & $(0.35)$ \\
\hline $\begin{array}{l}\text { Cumulative actual savings minus ESCO } \\
\text { payment }\end{array}$ & & 0.03 & $(0.01)$ & $(0.04)$ & 0.08 & 0.41 & 0.05 \\
\hline
\end{tabular}

Figure 11 compares what Fort Polk's annual utility payment would have been without the project (the post's actual utility bill plus actual savings from Table 4) to their costs with the ESPC (hypothetically, the actual utility bill plus a payment to the ESCO equal to 95\% of TMY savings).

Note that in 2000-2001, the sum of payments (utility bill plus ESCO payment) is lower than the utility bill Fort Polk would have paid without the project. On the other hand, in 2001-2002 the sum of payments is higher than the utility bill would have been without the project. The difference is partly a result of the weather: 2000-2001 is an extreme year (as evidenced by the high utility bill compared with other years) while 2001-2002 is a mild year. As shown in Appendix A, energy savings increase with increasing heating and cooling degree days, which means that savings are larger in more extreme years and smaller in milder years. Since the ESCO payment, or guarantee level, is based on $95 \%$ of savings in a TMY, then indeed, in some years the ESCO payment will exceed the actual savings. But this will happen in mild years when the overall utility bill will be lower and Fort Polk will have funds available to meet its obligation to the ESCO. 


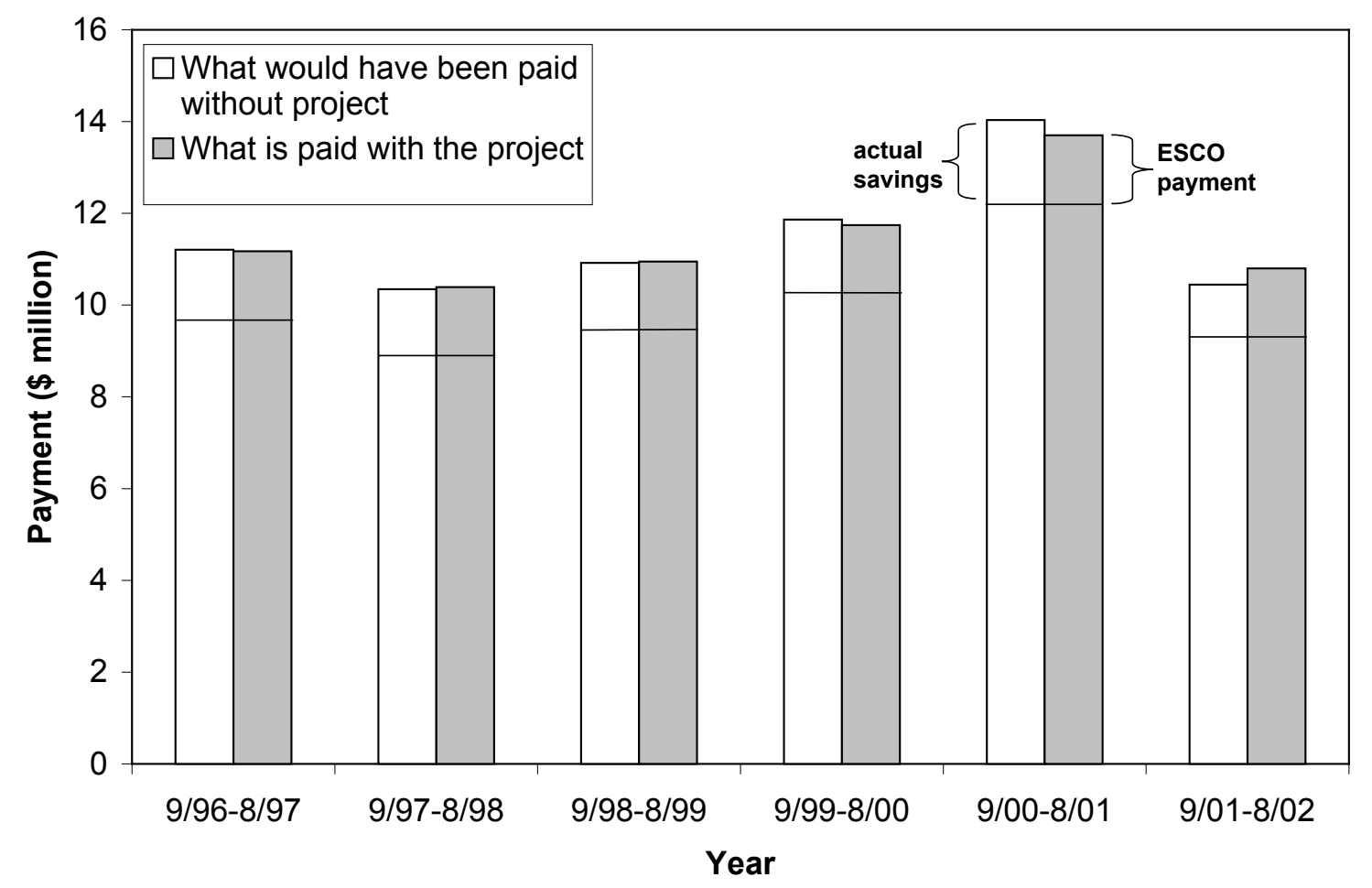

Figure 11. Comparison of what payments would have been without the project (total height of white bar) and with the project (total height of gray bar), when payments to the ESCO (and guaranteed savings) are escalated at $0.5 \%$ per year. Expenses without the project (white bar) equal the utility bill with the project plus the actual savings. Expenses with the project (gray bar) equal the utility bill with the project plus the ESCO payment.

Table 4 and Figure 11 assume that contracted savings are based on an electricity price escalation rate of $0.5 \%$ per year. Another way to estimate the escalation rate of electrical savings is to use the latest energy price forecasts from DOE's Energy Information Administration (DOE/EIA) and the National Institute of Standards and Technology (NIST), which are published annually. When the Fort Polk ESPC was signed, an escalation rate of about 3.9\% per year for commercial electricity prices was forecast (Lippiat 1992). As the comparisons in Table 5 show, the forecast significantly overestimated electricity price escalation between 1995 and 2001. If the ESCO payments equal $95 \%$ of the contracted savings in a TMY, payments to the ESCO exceed the actual savings in every year except 2000-2001. If DOE/EIA escalation rates had been used, by the fifth year payments to the ESCO would have exceeded actual savings by more than \$1 million.

Figure 12 shows the annual payments with the project and without the project. For every year except 2000-2001, payments with the project (i.e., the utility bill plus the ESCO payment) exceed what the utility bill would have been if the project had not been implemented. An obvious conclusion is that escalation rates have a significant impact on project cash flow, and therefore should be chosen with care. 


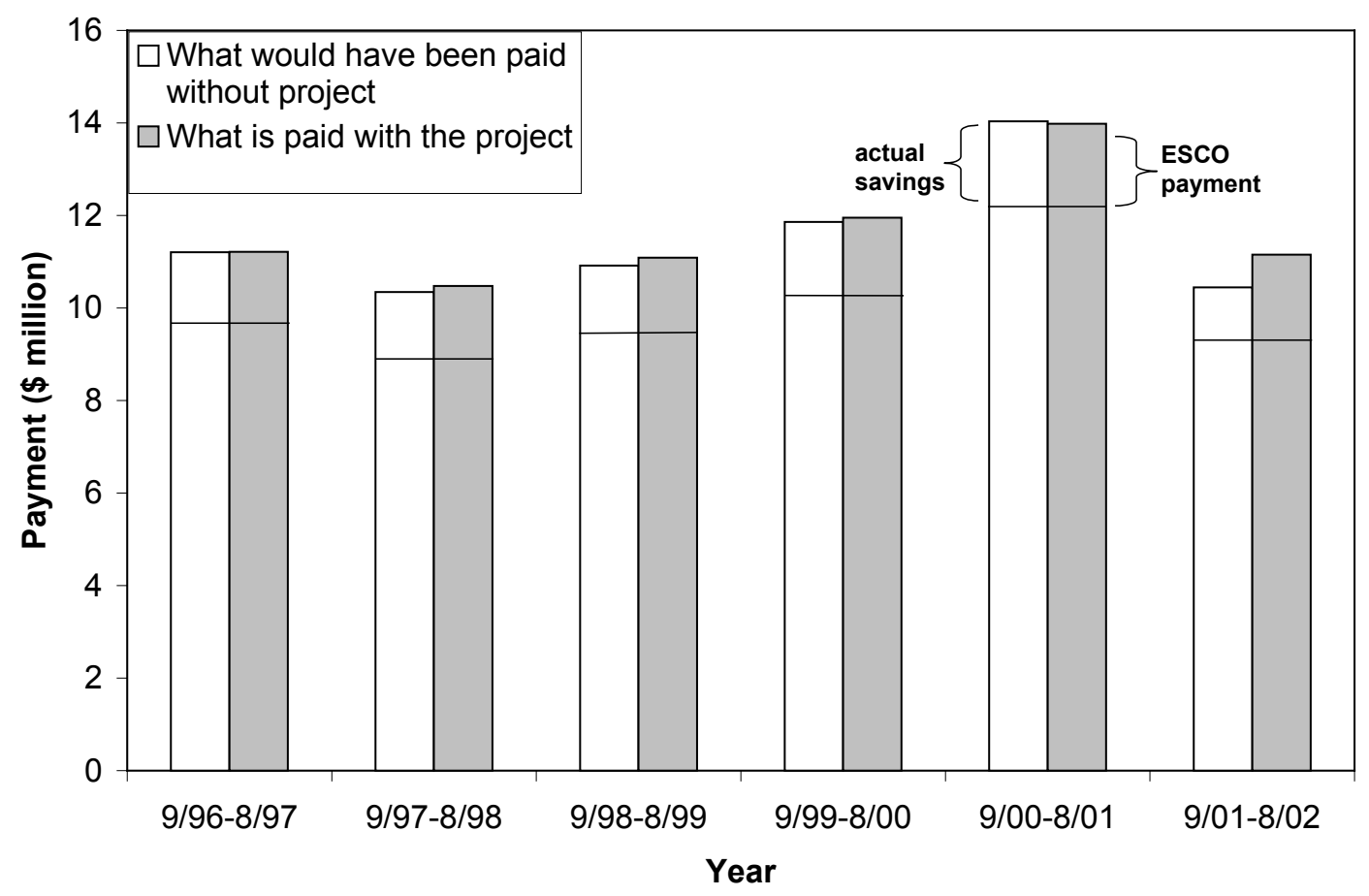

Figure 12. Comparison of what payments would have been without the project (total height of white bar) and with the project (total height of gray bar), when payments to the ESCO (and guaranteed savings) are escalated at DOE/EIA escalation rates current for 1993, 3.9\%. Expenses without the project (white bar) equal the utility bill with the project plus the actual savings. Expenses with the project (gray bar) equal the utility bill with the project plus the ESCO payment. In this case, the payments with the project exceed the payments without the project for every year except 2000-2001.

Table 5. Actual savings compared to contracted savings with EIA-forecasted energy price escalation of $3.9 \%$ per year, and compared to guaranteed savings ${ }^{a}$

\begin{tabular}{|c|c|c|c|c|c|c|c|}
\hline \multirow[b]{2}{*}{ Post-retrofit year $^{b}$} & \multicolumn{7}{|c|}{ Annual electricity use cost savings ( $\$$ millions) } \\
\hline & $\begin{array}{l}\text { Typical } \\
\text { year }\end{array}$ & $\begin{array}{c}1996- \\
97\end{array}$ & $\begin{array}{c}1997- \\
98\end{array}$ & $\begin{array}{c}1998- \\
99\end{array}$ & $\begin{array}{l}1999- \\
2000\end{array}$ & $\begin{array}{c}2000- \\
01\end{array}$ & $\begin{array}{c}2001- \\
02 \\
\end{array}$ \\
\hline $\begin{array}{l}\text { Actual savings (actual weather and price } \\
\text { escalation based on actual rates) }\end{array}$ & & 1.51 & 1.44 & 1.46 & 1.62 & 1.83 & 1.16 \\
\hline $\begin{array}{l}\text { Contracted savings }{ }^{c} \text { (TMY and EIA- } \\
\text { forecasted price escalation, } 3.9 \% \text { ) }\end{array}$ & 1.55 & 1.60 & 1.66 & 1.72 & 1.80 & 1.89 & 1.97 \\
\hline Actual minus contracted & & $(0.09)$ & $(0.22)$ & $(0.26)$ & $(0.18)$ & $(0.06)$ & $(0.81)$ \\
\hline Cumulative actual minus contracted & & $(0.09)$ & $(0.31)$ & $(0.57)$ & $(0.75)$ & $(0.80)$ & $(1.61)$ \\
\hline Guaranteed savings $^{d}$ (ESCO payment) & 1.47 & 1.52 & 1.57 & 1.63 & 1.71 & 1.79 & 1.87 \\
\hline $\begin{array}{l}\text { Actual savings minus guaranteed } \\
\text { savings }\end{array}$ & & $(0.01)$ & $(0.13)$ & $(0.17)$ & $(0.09)$ & 0.04 & $(0.71)$ \\
\hline $\begin{array}{l}\text { Cumulative actual savings minus } \\
\text { guaranteed savings }\end{array}$ & & $(0.01)$ & $(0.14)$ & $(0.31)$ & $(0.40)$ & $(0.36)$ & $(1.07)$ \\
\hline
\end{tabular}




\subsection{Summary of M\&V Best Practices}

Because of the difficulty (or impossibility) of discerning the reasons for changes in energy usage and peak demand reflected in utility bills, especially over the time spanned by many ESPC contracts, ESPC project M\&V is rarely based on utility bill analysis (M\&V Option C). The ECM-isolation methods (M\&V Options A and B) are by far the most commonly used, with some use of calibrated models (Option D) in special circumstances, such as GHP projects where detailed models must be developed anyway to properly size the ground heat exchanger.

Whether using Option A, B, or D to verify ESPC project savings, generally the ESCO's $\mathrm{M} \& \mathrm{~V}$-related risk and responsibility assignments extend only to the performance of the ECMs. ECM performance is generally translated into contracted cost savings assuming typical weather, pre-retrofit baseline load levels for the non-project-related loads, and stipulated energy cost escalation rates. The ESCO's contractual guarantees are met if contracted cost savings exceed the guarantee level each year.

According to FEMP guidance, the Risk and Responsibility Matrix and M\&V plan are to document the agreements between the agency and ESCO on assumptions and allocations of responsibilities and risks. Logic and cost-effectiveness drive the decisions for each project, and common sense dictates that the party that can control the risk should be responsible for it. Some patterns have emerged in the agreements reached in federal ESPC projects that are recognized as best practices and are generally followed, unless unusual circumstances warrant different arrangements:

- The ESCO designs the ECM application, selects the equipment, and installs and commissions the ECM, and is therefore held responsible for the ECM's fixed price and performance.

- Savings are normalized to typical weather (TMY).

- Since the government is responsible for mission-driven load fluctuations, loads not related to the project are set at pre-retrofit baseline levels for the purpose of calculating savings with marginal rate analysis.

- Facility operating hours are stipulated for the purpose of determining savings.

- Current energy price rate structures, and the marginal prices used to value ESPC savings that are derived from them, apply at the time of award; and agreed upon escalation rates apply for the rest of the contract term.

Engineering algorithms defined in the $M \& V$ plan consider all factors (performance, weather, non-project-related load, operating hours, and energy escalation rates) and, for the annual M\&V report, are used to determine contracted ECM cost savings as the difference between baseline and post-retrofit values. While it is true that contracted ECM cost savings may differ from actual ECM cost savings in a given year (because, for example, the weather was not typical or energy rates were not as forecasted), the fact remains that the government has remedies against the ESCO if the verified contracted cost savings do not match or exceed the guaranteed cost savings each year. When appropriate assumptions and choices are made, annual contracted and actual savings will 
be reasonably similar, and over the contract term contracted and actual savings tend to converge because weather and operating hours and other stipulated factors conform to the average over the long term.

According to FEMP guidance and in practice, the ESCO guarantees that the project's bundle of ECMs will result in a specified level of annual contracted cost savings, and the Risk and Responsibility Matrix and the M\&V plan in the project's delivery order award document the agreed-upon assumptions and allocations of responsibilities and risks. The alternative to using simplifying assumptions for the purpose of calculating savings having the ESCO take the risk that factors such as the weather, future energy rates, and the government's own operating hours and non-project-related loads will affect savings - would be a poor and expensive choice for the government.

\section{Implications for Agencies Deciding to Reconcile ESPC Savings and Utility Bills}

Agencies that decide to correlate the impact of individual ESPC projects directly to changes in their utility bills at either the site or agency level will probably need to consider implementing a system for tracking what their utility bills would have been if the energy efficiency projects had not been implemented. Most agencies have systems to track their actual energy use and costs across all agency sites, and perhaps these systems could be enhanced for this purpose.

Agencies would need to decide whether to track contracted savings, actual savings, or both. While the calculation of contracted savings is really the only practical option for annual guarantee verification in a long-term ESPC contract, it would be possible to estimate the actual savings at the end of the year as part of the annual M\&V report. Trying to capture actual savings of all past projects in a tracking system may not be feasible, but it might be possible to require that for current or future projects the ESCO would report both contracted and actual savings in the annual M\&V report, or to hire a third party to do so.

Contracted and actual savings are reasonably proximate to each other annually and converge over the contract term if appropriate assumptions and choices are made during project development. This being the case, the value of the extra effort required to calculate actual savings might be questionable. Potential benefits of going the extra mile would be to provide better guidance on "appropriate assumptions and choices" to use during project development and to monitor issues such as utility rate schedule changes.

\section{Conclusions}

This study shows that under the right circumstances analysis of utility bills can resolve savings from an ESPC project. Such circumstances are rare, however, and more costeffective and appropriate methods of verifying savings are widely recommended.

Our analysis of Fort Polk's utility bills unequivocally confirms and quantifies the savings resulting from the GHP retrofit accomplished at the facility in 1995 - 1996 under an 
ESPC. Using utility bills from 12 months immediately before and after the retrofits, we show that the annual electricity savings were $24.3 \pm 4.0$ million $\mathrm{kWh}$ (a $95 \%$ confidence interval) in the year after the retrofit, and that the utility bills predict peak summer demand savings of $7.27 \pm 3.1 \mathrm{MW}$. These results agree with our 1998 evaluation of the project (Hughes and Shonder 1998) based on detailed, submetered energy use data.

We were also able to resolve cost savings from analysis of Fort Polk's utility bills. Based on actual weather data for the months during the analysis period and actual electricity rate structures in effect during the period, we estimated annual electricity cost savings from the ESPC to be $\$ 1,450,000$.

Whether utility bill data can be used to discern persistence of electricity use and demand savings is another question. Fort Polk's utility bills indicate that the facility's total annual electricity use increased by about 13 million $\mathrm{kWh}$, or about half of the ESPC project's savings, between 1997 and 2003. Analysis of data from four feeders serving about 12\% of family housing - a large sample for such an analysis - shows that during this period electricity use in family housing increased about $2.2 \%$, or $0.31 \%$ per year, which is far less than the increase due to plug load growth that we predicted in 1998. The increase in electricity use in family housing accounts for about 1 million of Fort Polk's total 13 million $\mathrm{kWh}$ increase since 1996, indicating that savings due to the GHP retrofits have persisted and the majority of the increase in electricity use has occurred in areas other than family housing. These conclusions could not have been drawn solely from analysis of post-wide utility bills.

Utility bill analysis is seldom used for M\&V in federal ESPC projects because other methods of verifying savings are more practical, cost-effective, and reliable. FEMP M\&V guidelines (FEMP 2000) recommend against using simple utility bill analysis for federal ESPC projects. More complex regression modeling techniques may be appropriate, according to requirements specified by both ASHRAE and FEMP guidelines, where

- predicted savings are greater than about 10 to $20 \%$ of the site's energy use at the meter on a monthly basis (FEMP 2000, p. 164),

- the site has at least 12 and preferably 24 months of pre-installation data to calculate a baseline model, and

- the site has at least 9 and preferably 12 months of post-installation data to calculate first-year savings.

As this study shows, given sufficient data on a project of suitable scale in relation to the total facility energy use, utility bill analysis can resolve savings when comparing the periods immediately before and after the retrofits. However, factors that affect energy use change constantly, and those changes compound over the years. After the first year or two of the ESPC term utility bill analysis is inadequate for verifying savings because the method cannot be used to effectively distinguish between the performance of the installed ECMs and the effects of factors such as operating schedules, occupancy levels, or new or disconnected loads. Further, cost comparisons are complicated by changes in electricity rates, which affect the dollar value of energy and demand savings. 
The current state of the art in federal M\&V practices enables the government to costeffectively verify savings to an acceptable degree of certainty without allocating unmanageable risks to the ESCO that would burden projects with premium pricing and financing costs as compensation for bearing those risks. Several recognized best practices are generally followed in federal ESPC projects, unless unusual circumstances warrant different arrangements. Generally the ESCO's risks are limited to guaranteeing the performance of the ECMs, and guaranteed performance is translated into contracted cost savings assuming typical weather, pre-retrofit baseline load levels for the non-projectrelated loads, and stipulated energy cost escalation rates.

While contracted savings as calculated may differ from actual cost savings in a given year, contracted and actual savings will be reasonably similar and over the contract term the two values will tend to converge, if appropriate assumptions and choices have been made. This occurs because over time the actual weather (for example) will tend to conform to the same average used for the experience-based stipulation.

An additional margin of safety (and cost savings) is afforded by the fact that ESCOs universally guarantee less than $100 \%$ of estimated savings to increase their certainty of meeting the guarantee. And the fact remains that the government has remedies against the ESCO if the verified contracted cost savings do not match or exceed the guaranteed cost savings each year.

The alternative to using simplifying assumptions for the purpose of calculating savings - having the ESCO take the risk that factors such as the weather, future energy rates, and the government's own operating hours and non-project-related loads will affect savings - would be a poor and expensive choice for the government.

Agencies that decide to correlate the impact of individual ESPC projects directly to changes in their utility bills, either at the site or agency level, will probably need to consider implementing a system for tracking what their utility bills would have been if the energy efficiency projects had not been implemented. Since most agencies have systems to track their actual energy use and costs across all agency sites, perhaps these systems could be enhanced for this purpose. However, agencies will have to weigh the value of the extra effort required to calculate actual savings against its cost.

\section{References / Bibliography}

American Society of Heating, Refrigerating and Air-Conditioning Engineers, Inc. (ASHRAE). 2002. ASHRAE Guideline 14-2002, Measurement of Energy and Demand Savings.

Davidson, A. C., D. V. Hinkley, R. Gill, B. D. Ripley, S. Ross, M. Stein, D. Williams. 1977. Bootstrap Methods and Their Application. (Cambridge Series in Statistical and Probabilistic Mathematics, No. 1). Cambridge University Press. 
Federal Energy Management Program (FEMP). 2000. Measurement and Verification Guidelines for Federal Energy Projects, Version 2.2, DOE/GO-102000-0960. U.S. Department of Energy.

Hughes, P. J., and J. A. Shonder. 1998. The Evaluation of a 4000-Home Geothermal Heat Pump Retrofit at Fort Polk, Louisiana: Final Report, ORNL/CON-460, Oak Ridge National Laboratory, Oak Ridge, Tenn.

IPMVP Inc. 2001. International Performance Measurement and Verification Protocol. www.ipmvp.org.

Lippiat, Barbara C. 1992. Energy Prices and Discount Factors for Life-Cycle Cost Analysis 1993 - Annual Supplement to NIST Handbook 135 and NBS Special Publication 709. NIST 85-3273-7 (Rev. 10.92). U.S. Department of Commerce.

Reddy, T. A., N. F. Saman, D. E. Claridge, et al. 1977. "Baselining Methodology for Facility-Level Monthly Energy Use - Part 1: Theoretical Aspects.” ASHRAE Trans., 1977, vol. 103, part 2. 


\section{Appendix A: \\ Utility Bill Analysis to Determine Electrical Energy Savings}

Table A.1 presents the monthly electricity use in Fort Polk's North and South Fort areas for the last 12 months of the pre-retrofit period and the first 12 months of the post-retrofit period. Also included are the monthly base $-65^{\circ} \mathrm{F}$ heating and cooling degree days (HDD and CDD).

Table A.1. Pre- and post-retrofit monthly electricity use and base- $65^{\circ} \mathrm{F}$ heating and cooling degree days for North Fort and South Fort, Fort Polk

\begin{tabular}{|c|c|c|c|c|c|}
\hline & \multirow[b]{2}{*}{ Month } & \multirow[b]{2}{*}{ HDD } & \multirow[b]{2}{*}{ CDD } & \multicolumn{2}{|c|}{$\begin{array}{l}\text { Monthly electricity use } \\
(\mathrm{kWh})\end{array}$} \\
\hline & & & & South Fort & North Fort \\
\hline \multirow{12}{*}{ 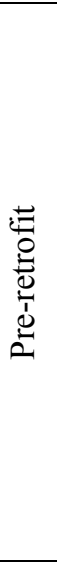 } & Mar-94 & 182 & 50 & $10,791,312$ & $2,334,600$ \\
\hline & Apr-94 & 66 & 155 & $11,711,616$ & $2,323,650$ \\
\hline & May-94 & 7 & 231 & $13,867,308$ & $2,686,450$ \\
\hline & Jun-94 & 0 & 450 & $16,129,008$ & $3,325,700$ \\
\hline & Jul-94 & 0 & 486 & $17,445,540$ & $3,511,700$ \\
\hline & Aug-94 & 0 & 451 & $17,338,440$ & $3,518,200$ \\
\hline & Sep-94 & 4 & 323 & $15,002,316$ & $2,908,100$ \\
\hline & Oct-94 & 57 & 165 & $12,693,408$ & $2,454,750$ \\
\hline & Nov-94 & 118 & 60 & $10,116,372$ & $2,114,200$ \\
\hline & Dec-94 & 346 & 13 & $10,521,756$ & $2,241,150$ \\
\hline & Jan-95 & 424 & 12 & $11,405,604$ & $2,629,900$ \\
\hline & Feb-95 & 276 & 7 & $9,874,032$ & $2,252,550$ \\
\hline \multirow{12}{*}{ 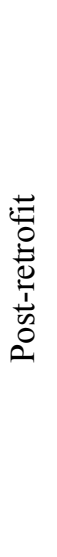 } & Sep-96 & 5 & 331 & $13,112,400$ & $2,720,950$ \\
\hline & Oct-96 & 41 & 147 & $10,815,084$ & $2,240,500$ \\
\hline & Nov-96 & 190 & 45 & $9,057,972$ & $1,984,100$ \\
\hline & Dec-96 & 311 & 21 & $9,313,584$ & $2,013,200$ \\
\hline & Jan-97 & 486 & 35 & $10,412,220$ & $2,571,250$ \\
\hline & Feb-97 & 321 & 23 & $8,923,068$ & $2,146,850$ \\
\hline & Mar-97 & 80 & 86 & $9,522,492$ & $2,128,550$ \\
\hline & Apr-97 & 86 & 48 & $9,299,304$ & $2,011,800$ \\
\hline & May-97 & 0 & 251 & $11,893,980$ & $2,334,900$ \\
\hline & Jun-97 & 0 & 401 & $13,884,024$ & $3,033,450$ \\
\hline & Jul-97 & 0 & 564 & $15,681,624$ & $3,455,950$ \\
\hline & Aug-97 & 0 & 511 & $15,210,300$ & $3,389,450$ \\
\hline
\end{tabular}

To normalize electricity use to a typical year at the site, we fit the pre- and post-retrofit monthly electrical energy use for each area of the base to a function of heating and cooling degrees:

$$
\mathrm{E}(\mathrm{kWh})=\mathrm{a}+\mathrm{h} \cdot \mathrm{HDD}+\mathrm{c} \cdot \mathrm{CDD}
$$


Then, since a typical year at Fort Polk contains 1909 heating degree days and 2493 cooling degree days, the energy use in a typical year is $12 \cdot \mathrm{a}+1909 \cdot \mathrm{h}+2493 \cdot \mathrm{c}$. The regression equations are as follows:

\section{$\underline{\text { Pre-retrofit }}$}

North Fort: $\quad \mathrm{E}=1,712,029+1,829 \cdot \mathrm{HDD}+3,766 \cdot \mathrm{CDD}$

South Fort: $\quad \mathrm{E}=9,177,092+3,638 \cdot \mathrm{HDD}+17,223 \cdot \mathrm{CDD}$

\section{$\underline{\text { Post-retrofit }}$}

North Fort: $\quad \mathrm{E}=1,636,307+1,457 \cdot \mathrm{HDD}+3,322 \cdot \mathrm{CDD}$

South Fort: $\quad \mathrm{E}=8,376,563+2,249 \cdot \mathrm{HDD}+13,475 \cdot \mathrm{CDD}$

Substituting in the heating and cooling degree days for a typical year into each of the four equations in turn gives the results shown in Table A.2, which also provides estimated 95\% confidence intervals for each of the parameters, obtained using a bootstrap technique (Davison 1997).

Table A.2. Weather-normalized annual electricity use (million kWh)

\begin{tabular}{lrrr}
\hline & Pre-retrofit & Post-retrofit & Savings \\
\hline North Fort & $33.4 \pm 0.6$ & $30.8 \pm 0.6$ & $2.7 \pm 0.9$ \\
South Fort & $160.0 \pm 3.4$ & $138.4 \pm 2.0$ & $21.6 \pm 3.9$ \\
Total & $193.4 \pm 3.4$ & $169.2 \pm 2.1$ & $24.3 \pm 4.0$ \\
\hline
\end{tabular}

Statistical analyses of the regression equations are presented in tables A.3 through A.6.

Table A.3. Regression analysis of pre-retrofit monthly energy use in North Fort

\begin{tabular}{lrrrr}
\hline & Coefficients & Std Error & t-Stat & p-value \\
\hline Intercept & $1,712,029$ & 92,196 & 18.6 & $1.75 \mathrm{E}-08$ \\
HDD & 1,829 & 324 & 5.7 & $3.12 \mathrm{E}-04$ \\
CDD & 3,766 & 263 & 14.3 & $1.67 \mathrm{E}-07$ \\
\hline R-squared: & & 0.9713 & & \\
Adjusted r-squared: & 0.965 & & \\
\hline
\end{tabular}


Table A.4. Regression analysis of pre-retrofit monthly energy use in South Fort

\begin{tabular}{crccc}
\hline & Coefficients & Std Error & $\mathrm{t}$-Stat & $\mathrm{p}$-value \\
\hline Intercept & $9,177,092$ & 500,022 & 18.4 & $1.93 \mathrm{E}-08$ \\
HDD & 3,638 & 1,755 & 2.1 & $6.81 \mathrm{E}-02$ \\
CDD & 17,223 & 1,424 & 12.1 & $7.21 \mathrm{E}-07$ \\
\hline R-squared: & & 0.9722 & & \\
Adjusted r-squared: & 0.9660 & & \\
\hline
\end{tabular}

Table A.5. Regression analysis of post-retrofit monthly energy use in North Fort

\begin{tabular}{lrrrc}
\hline & Coefficients & Std Error & t-Stat & p-value \\
\hline Intercept & $1,636,307$ & 75,746 & 21.6 & $4.60 \mathrm{E}-09$ \\
HDD & 1,457 & 258 & 5.7 & $3.12 \mathrm{E}-04$ \\
CDD & 3,322 & 210 & 15.8 & $7.23 \mathrm{E}-08$ \\
\hline R-squared: & & 0.9716 & & \\
Adjusted r-squared: & 0.9653 & & \\
\hline
\end{tabular}

Table A.6. Regression analysis of post-retrofit monthly energy use in South Fort

\begin{tabular}{lrrrl}
\hline & Coefficients & Std Error & t-Stat & p-value \\
\hline Intercept & $8,376,563$ & 246,991 & 33.9 & $8.31 \mathrm{E}-11$ \\
HDD & 2,249 & 840 & 2.7 & $2.53 \mathrm{E}-02$ \\
CDD & 13,475 & 686 & 19.6 & $1.07 \mathrm{E}-08$ \\
\hline R-squared: & & 0.9859 & & \\
Adjusted r-squared: & 0.9828 & & \\
\hline
\end{tabular}




\section{Appendix B: \\ Utility Bill Analysis to Determine Electricity Demand Savings}

As one might expect, patterns of peak electrical demand were much more difficult to understand than patterns of monthly electricity use. To get a better idea of what was happening, we used all 18 months of available pre-retrofit data and 24 months of postretrofit data, instead of just one year pre- and post-retrofit as we did with the energy use data.

The reason is that in the pre-retrofit period, billed peak demand in both areas of Fort Polk depended on the season: For the most part, peak monthly demand in November through February was a function of the monthly low temperature, while in March through October peak monthly demand was a function of the monthly high temperature. However, because family housing made up $67 \%$ of the pre-retrofit electricity load in North Fort (compared with only $37 \%$ in South Fort), the supplemental resistance heating on the pre-retrofit heat pumps caused North Fort to have more winter-peaking months than the South Fort. For example, in March 1994 demand in North Fort seemed to follow the pattern for a winter month, while demand in South Fort followed the pattern of a summer month. In February of 1995, North Fort also followed the winter pattern while South Fort followed the summer pattern.

With only three or four heating months, one year's data was insufficient to develop meaningful regressions. Thus Table B.1 presents the monthly billed peak demand in Fort Polk's North Fort and South Fort areas for the last 18 months of the pre-retrofit period, and Table B.2 presents the peak demands for the first 24 months of post-retrofit period. The tables include monthly high and low temperatures, and indicate for each month whether the demand followed the winter or summer pattern. This data was used to estimate demand savings.

Figure B.1 plots monthly peak demand for the South Fort, pre- and post-retrofit. In the pre-retrofit period, peak demand was a linear function of monthly high temperature during summer months and a linear function of monthly low temperature in the winter months. In the post-retrofit period, monthly peak demand is strictly a function of the monthly high temperature. Clearly, the winter peaking was caused by electric supplemental heating on the pre-retrofit heat pumps. Once the heat pumps were replaced with GHPs (which have no supplemental heat) the winter peak disappeared.

Figure B.2 plots pre- and post-retrofit monthly billed peak demand for North Fort. With smaller electricity loads in this area the data shows more scatter than that of the South Fort, but the pattern is still clear. Note that the August 1993 peak demand of $9740 \mathrm{~kW}$ is an outlier. 
Table B.1. Pre-retrofit monthly billed peak demand and monthly high and low temperatures

\begin{tabular}{|c|c|c|c|c|c|c|}
\hline \multirow[b]{2}{*}{ Month } & \multicolumn{2}{|c|}{ Temperature $\left({ }^{\circ} \mathrm{F}\right)$} & \multicolumn{2}{|c|}{ South Fort } & \multicolumn{2}{|c|}{ North Fort } \\
\hline & High & Low & $\begin{array}{c}\text { Peak demand } \\
(\mathrm{kW})\end{array}$ & Season & $\begin{array}{c}\text { Peak demand } \\
(\mathrm{kW})\end{array}$ & Season \\
\hline Jun-93 & 96 & 58 & 30,072 & Summer & 5,920 & Summer \\
\hline Jul-93 & 99 & 71 & 32,424 & Summer & 5,760 & Summer \\
\hline Aug-93 & 101 & 72 & 33,399 & Summer & 9,740 & Summer \\
\hline Sep-93 & 99 & 51 & 31,786 & Summer & 6,820 & Summer \\
\hline Oct-93 & 89 & 30 & 26,107 & Summer & 5,040 & Summer \\
\hline Nov-93 & 84 & 29 & 19,421 & Winter & 5,240 & Winter \\
\hline Dec-93 & 75 & 28 & 20,496 & Winter & 5,200 & Winter \\
\hline Jan-94 & 72 & 21 & 25,133 & Winter & 7,900 & Winter \\
\hline Feb-94 & 78 & 24 & 23,923 & Winter & 7,020 & Winter \\
\hline Mar-94 & 83 & 32 & 21,034 & Summer & 6,020 & Winter \\
\hline Apr-94 & 87 & 36 & 25,805 & Summer & 5,240 & Summer \\
\hline May-94 & 87 & 53 & 26,813 & Summer & 6,160 & Summer \\
\hline Jun-94 & 94 & 66 & 30,778 & Summer & 6,920 & Summer \\
\hline Jul-94 & 94 & 63 & 31,752 & Summer & 6,600 & Summer \\
\hline Aug-94 & 93 & 63 & 30,576 & Summer & 6,700 & Summer \\
\hline Sep-94 & 93 & 48 & 29,602 & Summer & 6,160 & Summer \\
\hline Oct-94 & 91 & 43 & 26,712 & Summer & 5,160 & Summer \\
\hline Nov-94 & 84 & 44 & 21,538 & Summer & 4,700 & Summer \\
\hline Dec-94 & 78 & 29 & 21,336 & Winter & 5,520 & Winter \\
\hline Jan-95 & 76 & 25 & 23,285 & Winter & 6,660 & Winter \\
\hline Feb-95 & 78 & 30 & 22,075 & Summer & 6,600 & Winter \\
\hline
\end{tabular}


Table B.2. Post-retrofit monthly billed peak demand and monthly high and low temperatures

\begin{tabular}{lcccccc}
\hline & Temperature $\left({ }^{\circ} \mathrm{F}\right)$ & \multicolumn{2}{c}{ South Fort } & \multicolumn{2}{c}{ North Fort } \\
\cline { 3 - 5 } Month & High & Low & $\begin{array}{c}\text { Peak } \\
\text { demand } \\
(\mathrm{kW})\end{array}$ & Season & $\begin{array}{c}\text { Peak } \\
\text { demand } \\
(\mathrm{kW})\end{array}$ & Season \\
\hline Oct-96 & 86 & 39 & 20,899 & Summer & 4,540 & Summer \\
Nov-96 & 82 & 32 & 19,891 & Summer & 4,400 & Summer \\
Dec-96 & 79 & 19 & 17,808 & Summer & 4,500 & Summer \\
Jan-97 & 79 & 23 & 18,379 & Summer & 5,520 & Summer \\
Feb-97 & 81 & 32 & 17,775 & Summer & 4,440 & Summer \\
Mar-97 & 86 & 43 & 17,069 & Summer & 4,000 & Summer \\
Apr-97 & 88 & 39 & 20,227 & Summer & 4,160 & Summer \\
May-97 & 90 & 52 & 24,159 & Summer & 4,460 & Summer \\
Jun-97 & 93 & 59 & 25,872 & Summer & 5,900 & Summer \\
Jul-97 & 97 & 68 & 26,981 & Summer & 6,140 & Summer \\
Aug-97 & 97 & 63 & 27,048 & Summer & 6,260 & Summer \\
Sep-97 & 95 & 59 & 25,267 & Summer & 5,940 & Summer \\
Oct-97 & 90 & 39 & 23,285 & Summer & 5,260 & Summer \\
Nov-97 & 77 & 30 & 15,994 & Summer & 4,100 & Summer \\
Dec-97 & 73 & 28 & 16,968 & Summer & 4,320 & Summer \\
Jan-98 & 73 & 30 & 16,699 & Summer & 4,360 & Summer \\
Feb-98 & 73 & 34 & 16,263 & Summer & 4,160 & Summer \\
Mar-98 & 81 & 28 & 17,103 & Summer & 4,400 & Summer \\
Apr-98 & 82 & 43 & 19,522 & Summer & 4,080 & Summer \\
May-98 & 99 & 57 & 24,763 & Summer & 4,800 & Summer \\
Jun-98 & 99 & 59 & 27,351 & Summer & 6,520 & Summer \\
Jul-98 & 104 & 72 & 27,485 & Summer & 6,600 & Summer \\
Aug-98 & 104 & 70 & 27,519 & Summer & 6,560 & Summer \\
Sep-98 & 97 & 70 & 27,048 & Summer & 6,000 & Summer \\
\hline
\end{tabular}




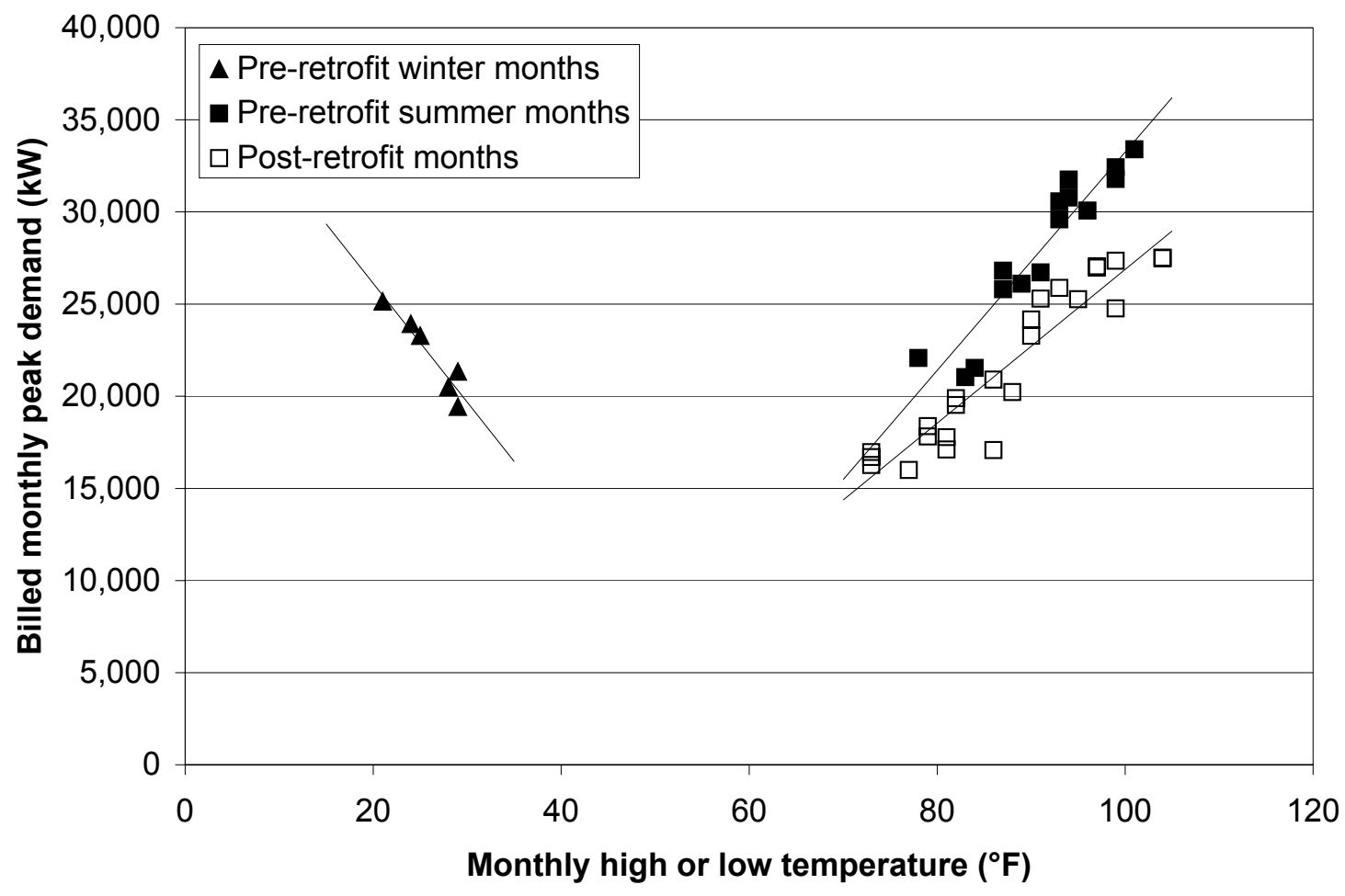

Figure B.1. South Fort billed monthly peak demand, pre- and post-retrofit. Before the retrofit, there are winter and summer peaks, whereas post-retrofit peak demand is always a function of monthly high temperature. 


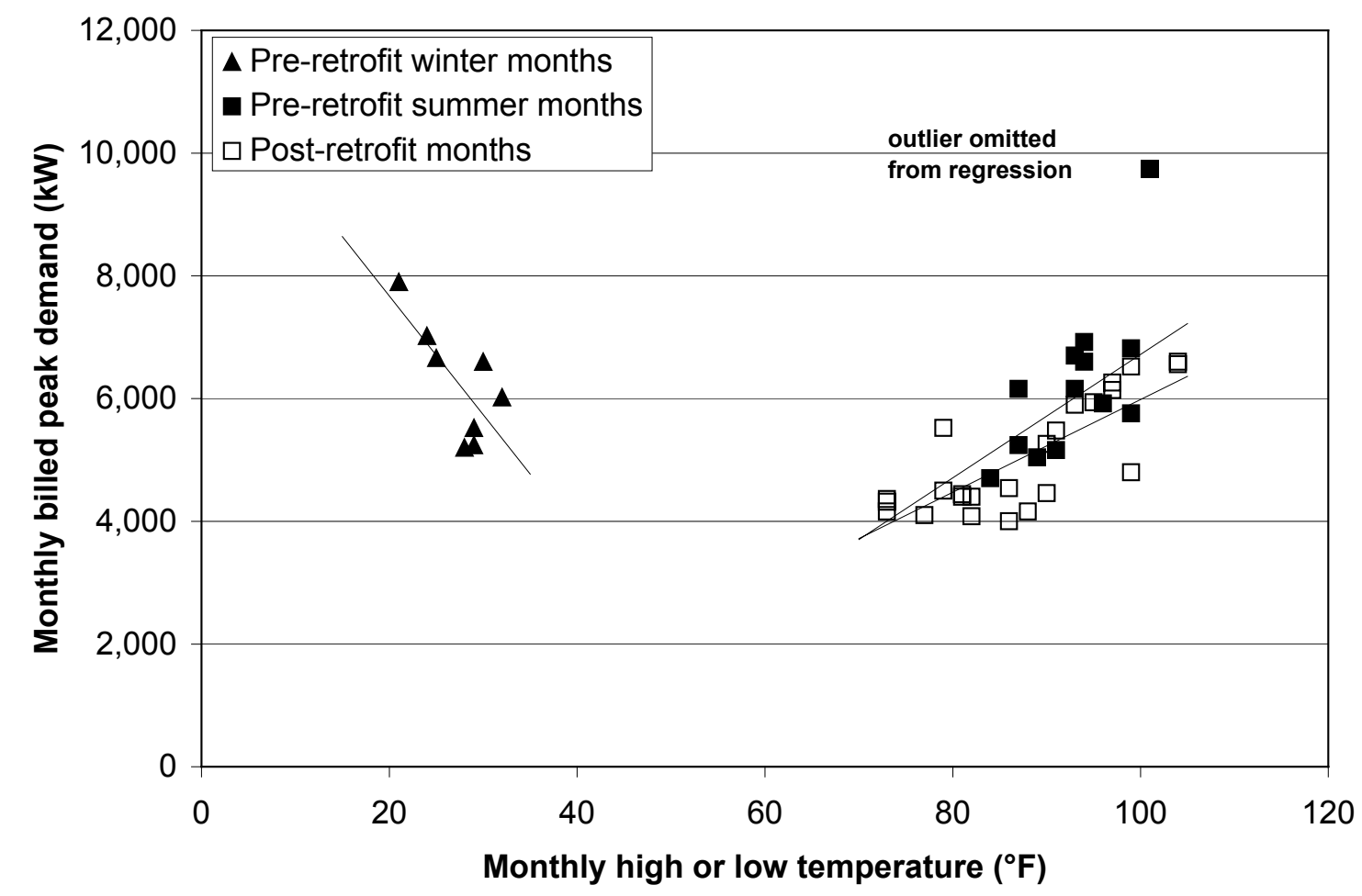

Figure B.2. North Fort billed monthly peak demand. Pre-retrofit demand had winter and summer peaks, while post-retrofit peak demand is always a function of monthly high temperature.

To estimate peak demand savings in a typical year, we began by correlating monthly billed peak demand with monthly low temperature for pre-retrofit winter months, and with monthly high temperature for pre-retrofit summer months and all post-retrofit months. The outlier in Figure B.2 was omitted because, even if this was not a billing error, omitting the outlier leads to a conservative estimate of peak demand savings, and there is no plausible justification for attributing the value to pre-retrofit housing as opposed to a one-month mission-related anomaly. The regression equations are the following.

$\underline{\text { Pre-retrofit }}$

North Fort summer demand $(\mathrm{kW})=100.5 \cdot \mathrm{T}_{\max }-3333.4$

North Fort winter demand $(\mathrm{kW})=\quad-193.4 \cdot \mathrm{T}_{\min }+11,541$

South Fort summer demand $(\mathrm{kW})=592.2 \cdot \mathrm{T}_{\max }-25,976$

South Fort winter demand $(\mathrm{kW})=\quad-644.9 \cdot \mathrm{T}_{\min }+39,032$

$\underline{\text { Post-retrofit }}$

North Fort demand $(\mathrm{kW})=$

$75.6 \cdot \mathrm{T}_{\max }-1571.4$

South Fort demand $(\mathrm{kW})=$

$417.1 \cdot \mathrm{T}_{\max }-14,829$ 
In a typical year at Fort Polk, the annual low temperature is $19.9^{\circ} \mathrm{F}$, and the annual high is $100.9^{\circ} \mathrm{F}$. Equations (B.1a) and (B.1b) show that in the pre-retrofit period, the peak demand for North Fort would occur in the winter, at $7692 \mathrm{~kW}$ compared with $6807 \mathrm{~kW}$ in the summer. However, the overall pre-retrofit peak would occur in the summer when, according to Eq. (B.2a), the demand in the South Fort is $33,777 \mathrm{~kW}$. Combined with the $6807 \mathrm{~kW}$ in North Fort, annual peak demand in a typical year would be 40,584 kW.

The post-retrofit peak demand in the North Fort in a typical year is $6057 \mathrm{~kW}$, and peak demand in South Fort is $27,256 \mathrm{~kW}$, for a combined peak of $33,313 \mathrm{~kW}$. The demand savings for a typical year is then $40,584-33,313=7271 \mathrm{~kW}$.

To estimate the uncertainty in the estimate of demand savings, we used a bootstrap technique (Davison 1997). A 95\% confidence interval for the demand savings is $7.3 \pm$ $3.1 \mathrm{MW}$.

Statistical analyses of Eqs. (B.1) through (B.4) are presented in tables B.3 through B.8.

Table B.3. Regression analysis of North Fort pre-retrofit cooling peak demand

\begin{tabular}{lrrrr}
\hline & Coefficients & Std Error & t Stat & P-value \\
\hline Intercept & -3333.4 & 3624.1 & -0.92 & 0.3793 \\
$\mathrm{~T}_{\max }$ & 100.52 & 39.27 & 2.56 & $2.84 \mathrm{E}-02$ \\
\hline R-squared & & 0.3958 & & \\
Adjusted r-squared & 0.3354 & & \\
\hline
\end{tabular}

Table B.4. Regression analysis of North Fort pre-retrofit heating peak demand

\begin{tabular}{lrrrr}
\hline & Coefficients & Std Error & t Stat & P-value \\
\hline Intercept & $11,541.3$ & $1,991.3$ & 5.80 & 0.0012 \\
$\mathrm{~T}_{\max }$ & -193.44 & 72.52 & -2.67 & $3.72 \mathrm{E}-02$ \\
\hline R-squared & & 0.5425 & & \\
Adjusted r-squared & 0.4663 & & \\
\hline
\end{tabular}

Table B.5. Regression analysis of South Fort pre-retrofit cooling peak demand

\begin{tabular}{lrrrr}
\hline & Coefficients & Std Error & t Stat & P-value \\
\hline Intercept & $-25,976.2$ & $5,297.6$ & -4.90 & 0.0003 \\
$\mathrm{~T}_{\text {max }}$ & 592.19 & 57.95 & 10.22 & $1.40 \mathrm{E}-07$ \\
\hline R-squared & & 0.8893 & & \\
Adjusted r-squared & 0.8808 & & \\
\hline
\end{tabular}


Table B.6. Regression analysis of South Fort pre-retrofit heating peak demand

\begin{tabular}{lrrrr}
\hline & Coefficients & Std Error & $\mathrm{t}$ Stat & P-value \\
\hline Intercept & $39,032.2$ & $2,852.1$ & 13.69 & 0.0002 \\
$\mathrm{~T}_{\max }$ & -644.87 & 109.00 & -5.92 & $4.09 \mathrm{E}-03$ \\
\hline R-squared & & 0.8974 & & \\
Adjusted r-squared & 0.8718 & & \\
\hline
\end{tabular}

Table B.7. Regression analysis of North Fort post-retrofit peak demand

\begin{tabular}{lrrrr}
\hline & Coefficients & Std Error & $\mathrm{t}$ Stat & P-value \\
\hline Intercept & -1571.4 & 1072.8 & -1.46 & 0.1571 \\
$\mathrm{~T}_{\max }$ & 75.57 & 12.20 & 6.20 & $3.09 \mathrm{E}-06$ \\
\hline R-squared & & 0.6357 & & \\
Adjusted r-squared & 0.6192 & & \\
\hline
\end{tabular}

Table B.8. Regression analysis of South Fort post-retrofit peak demand

\begin{tabular}{lrrrr}
\hline & Coefficients & Std Error & $\mathrm{t}$ Stat & P-value \\
\hline Intercept & $-14,828.9$ & $2,858.4$ & -5.19 & $3.35 \mathrm{E}-05$ \\
$\mathrm{~T}_{\max }$ & 417.11 & 32.49 & 12.84 & $1.08 \mathrm{E}-11$ \\
\hline R-squared & 0.8822 & & \\
Adjusted r-squared & 0.8769 & & \\
\hline
\end{tabular}




\section{Appendix C: Analysis to Determine Persistence of Savings}

The energy conservation measures installed in 1995 - 1996 had a definite impact on electricity use and demand at Fort Polk, shown clearly in Figures 2 and 3 of the body of the report. But starting in about August of 2000, total Fort Polk electricity use began a steady rise, and by June 2003 the weather-normalized annual consumption was about half way back to the where it was before the conservation measures were installed. What happened? Was there a take-back effect in family housing, or did this increase take place in the non-housing areas of Fort Polk?

At Fort Polk, electricity is supplied to family housing through 16 separate electrical feeders. Each feeder contains a submeter that the Army reads manually once per month to track family housing electricity use. We obtained these manual readings for the same period for which we obtained Fort Polk's utility bills, June 1993 to June 2003. Figure C.1 presents the sum of these monthly meter readings for the 16 feeders. As with electricity use for the entire facility, the raw data is not very informative. There seems to be a drop in electricity use around the time the energy conservation measures were installed, but the scatter in the data makes the reduction difficult to quantify.

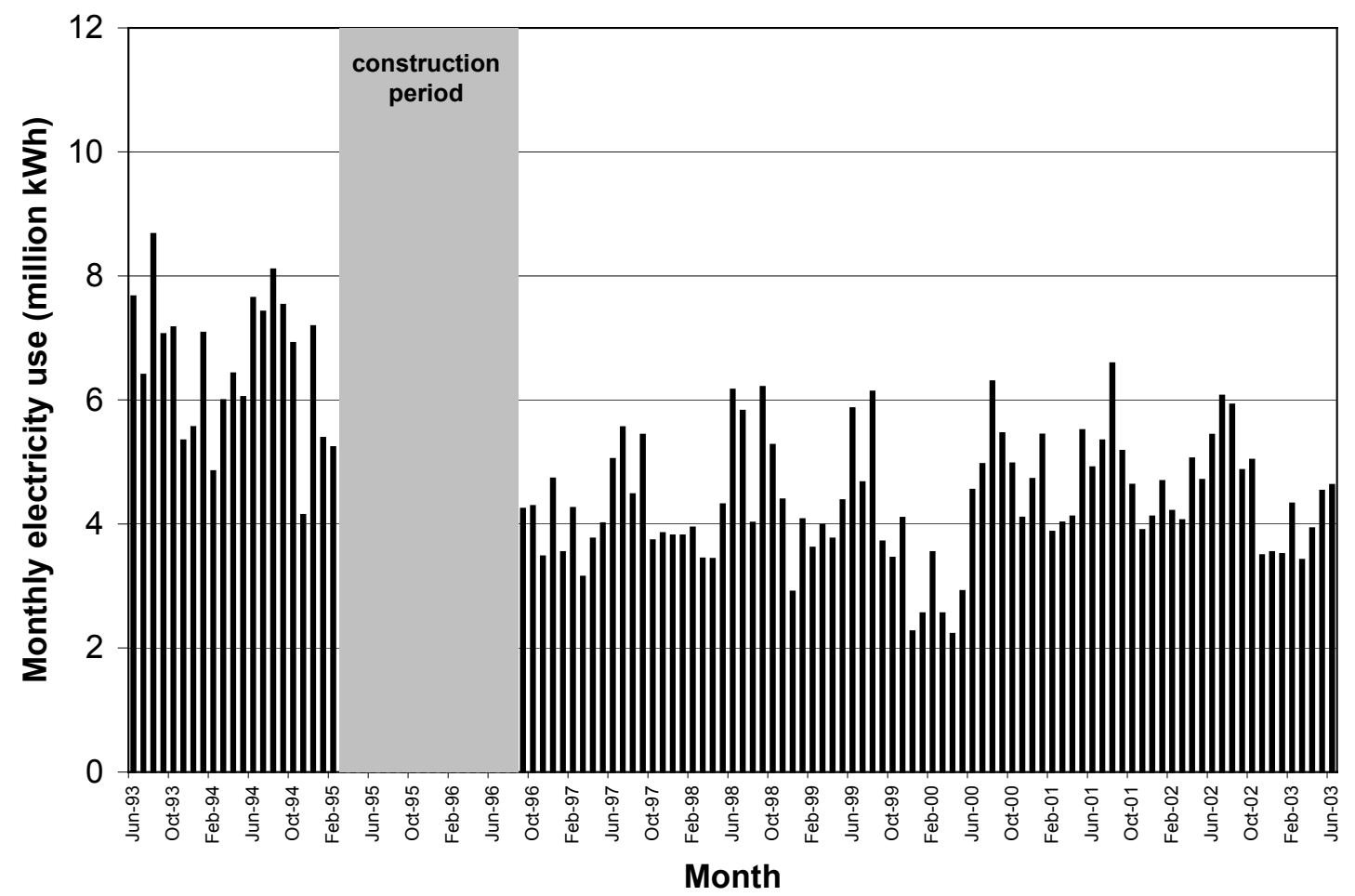

Figure C.1. Monthly sums of readings from the $\mathbf{1 6}$ electric submeters in the family housing areas of Fort Polk. 
Figure C.2, which takes data from the 12 months ending with the graphed months and normalizes the data to a TMY, makes it much clearer what has happened, at least initially. Annual electricity use in family housing fell from about 77-79 million kWh per year before the retrofits to about 51-53 million $\mathrm{kWh}$ per year afterwards. It remained at this level for several years, but between September 1999 and July 2000, energy use suddenly dropped by $21 \%$, then increased by about $41 \%$ over the next 14 months (this trough is visible in Figure C.1 as well).

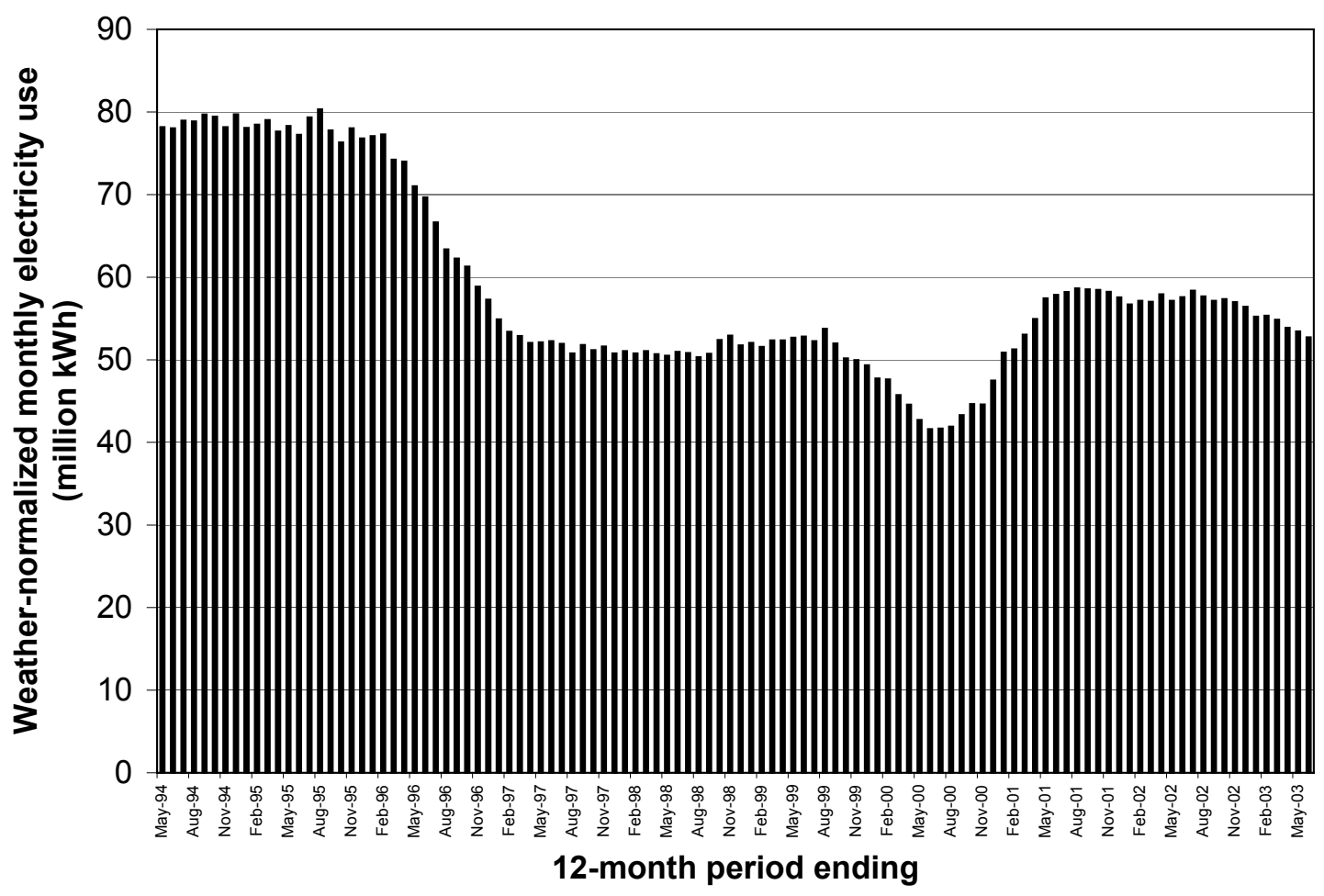

Figure C.2. Annual electricity use in Fort Polk family housing. The bars represent weathernormalized $\mathrm{kWh}$ for the 12-month period ending with the graphed month.

One factor that could have changed energy use in family housing is demolition of housing units: Between September 1998 and August 2002, a total of 362 older residences were demolished, leaving only 3641 of the original 4003 units. About 10.4\% of the original square footage of housing was demolished, leaving $89.7 \%$. But in Figure C. 3 we overlay the percentage of remaining housing square footage on the weathernormalized manual meter readings. Obviously, demolition of housing units does not account for what the data are showing. For this reason, we believe the manual readings from the family housing meters are unreliable.

In our original study of the Fort Polk retrofit project, we attached data loggers to 14 of the 16 family housing electric submeters in order to read them electronically at 15-minute intervals. In July 2003, we were able to rehabilitate 11 of our original 14 data loggers and began collecting electric use data once again. To date the results have been mixed. For example, Figure C.4 presents daily electricity use vs. daily average temperature on 


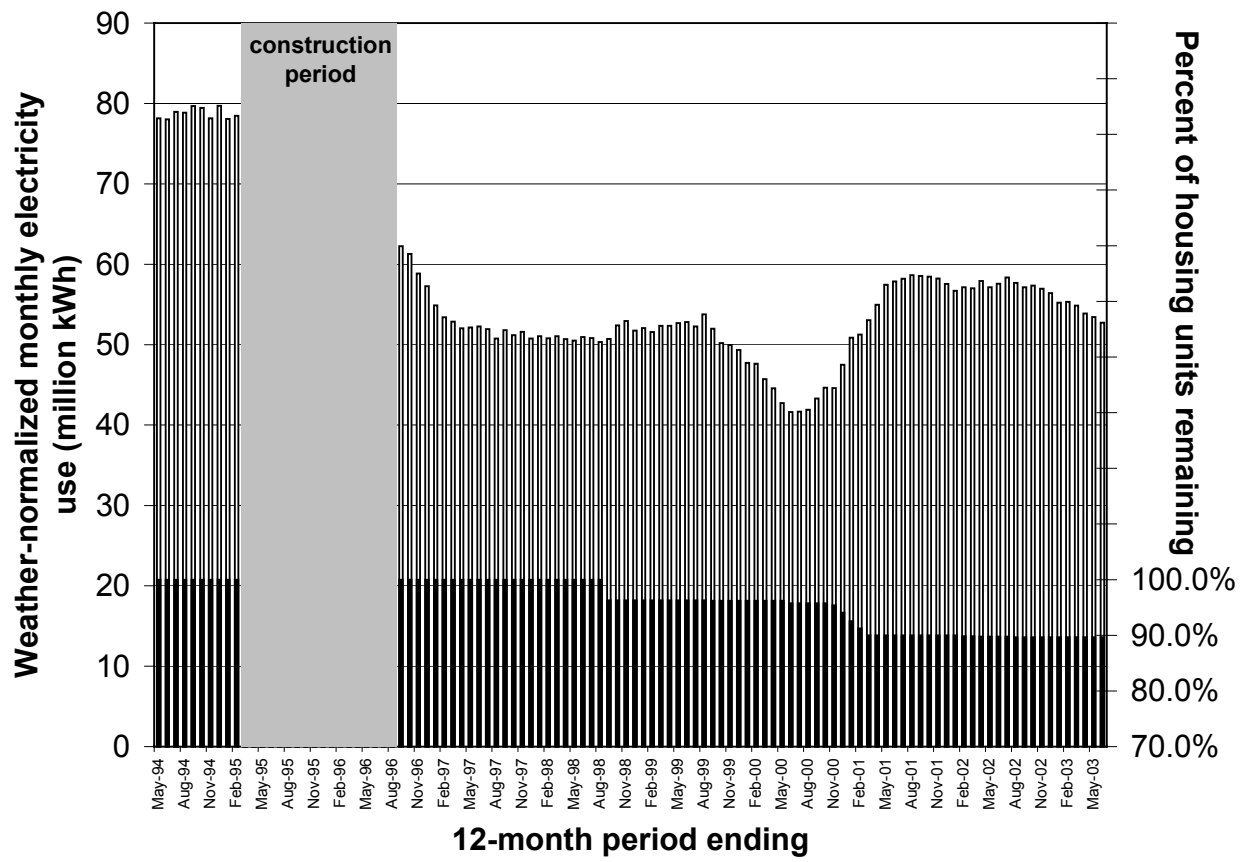

Figure C.3. Weather-normalized total of manually read submeters in family housing, and percentage of original housing units remaining. Each bar represents $\mathrm{kWh}$ for the 12month period ending with the graphed month.

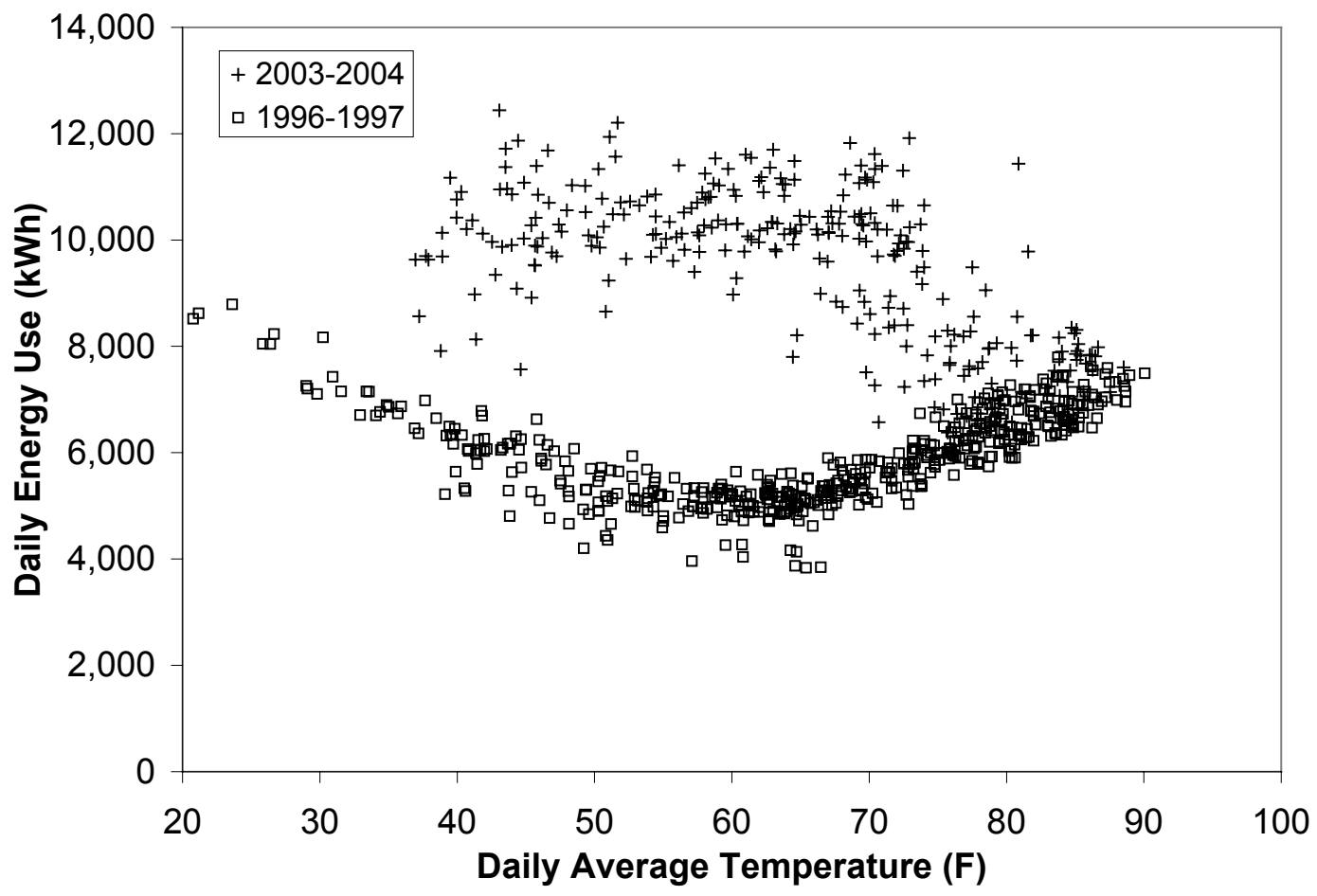

Figure C.4. Daily electricity use vs. daily average temperature for submetered Feeder 5, 1996-1997 and 2003-2004. Either this meter was not working correctly in 2003-2004, or the feeder serves a different set of loads than it did in $1996-1997$. 
Feeder 5 from our original data collection effort from 1996 to 1997, along with the more recent data. In 1996-1997, the data had the expected pattern for electricity use in allelectric housing - more energy was used at the extreme temperatures in both summer (for cooling) and in winter (for heating). But in the later data, the pattern seems to be inverted - less energy is used as outdoor air temperatures become more extreme. Either this meter is no longer functioning properly, or the electricity use is no longer limited to housing.

Another example is presented in Figure C.5, which plots daily energy use vs. daily average temperature for Feeder 14. Here at least the more recent data corresponds to what we expect for a housing load, but the number of housing units served by this feeder seems to have increased drastically. In 1996-1997, baseline energy use (i.e., the portion unaffected by heating and cooling) was about $1800 \mathrm{kWh}$ per day, whereas in 2003-2004 it has increased to $5300 \mathrm{kWh}$ per day. This is nearly a $300 \%$ increase, and clearly much greater than one would expect from an increase in electric appliances.

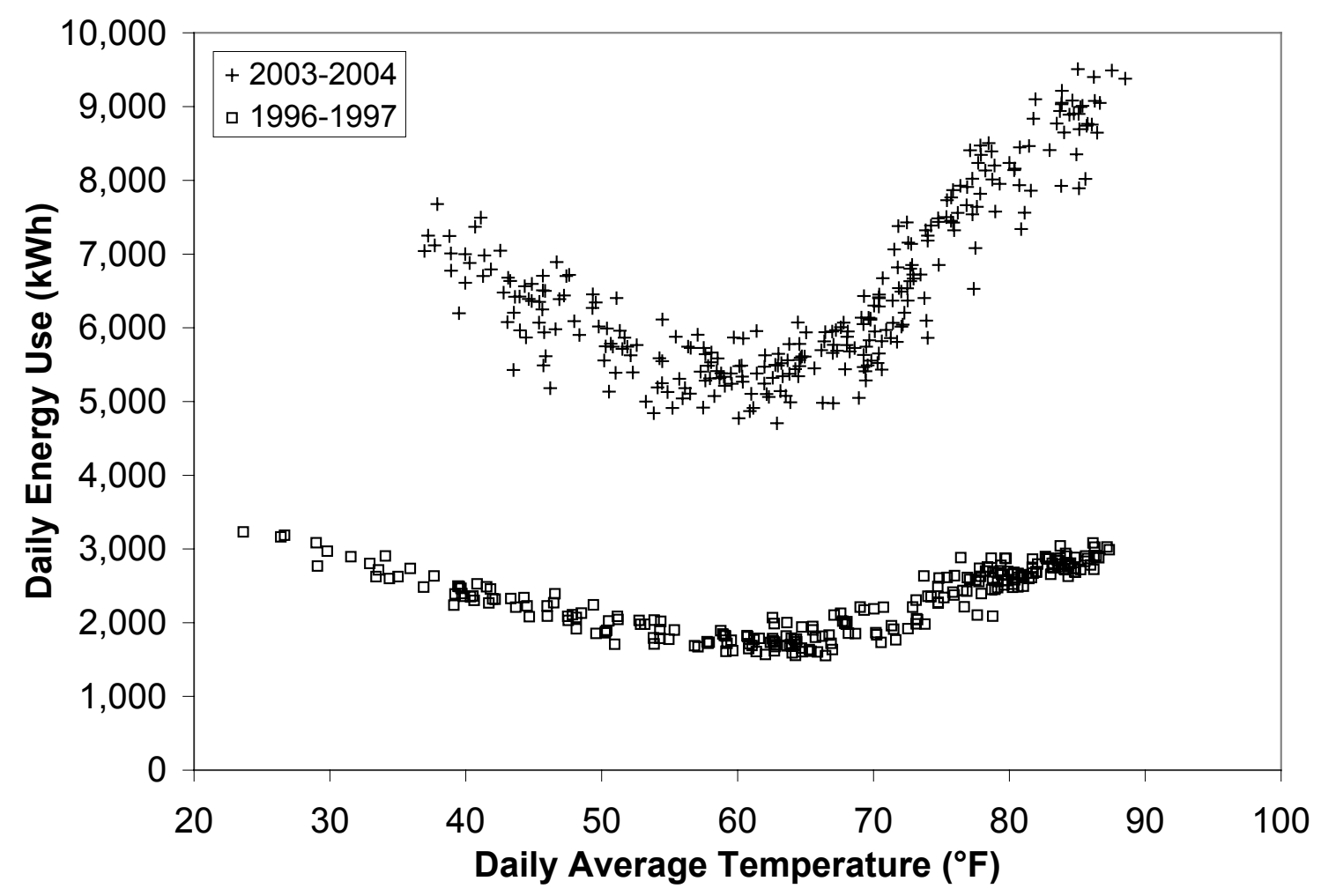

Figure C.5. Daily energy use on Feeder 14 increased after 1996-1997 by nearly 300\% according to data gathered in 2003-2004, but this increase is certainly due to an increase of housing units being served by the feeder.

Altogether, of the eleven feeders we rehabilitated in 2003, data from seven are so different from the 1996-1997 data as to be unusable. On the other hand, data from four of the eleven feeders (Feeders 3, 4, 6, and 16) were very similar to the 1996-1997 data, as 
can be seen in Figure C.6. Coincidentally, there were no demolitions on these feeders, so their energy use is directly comparable.
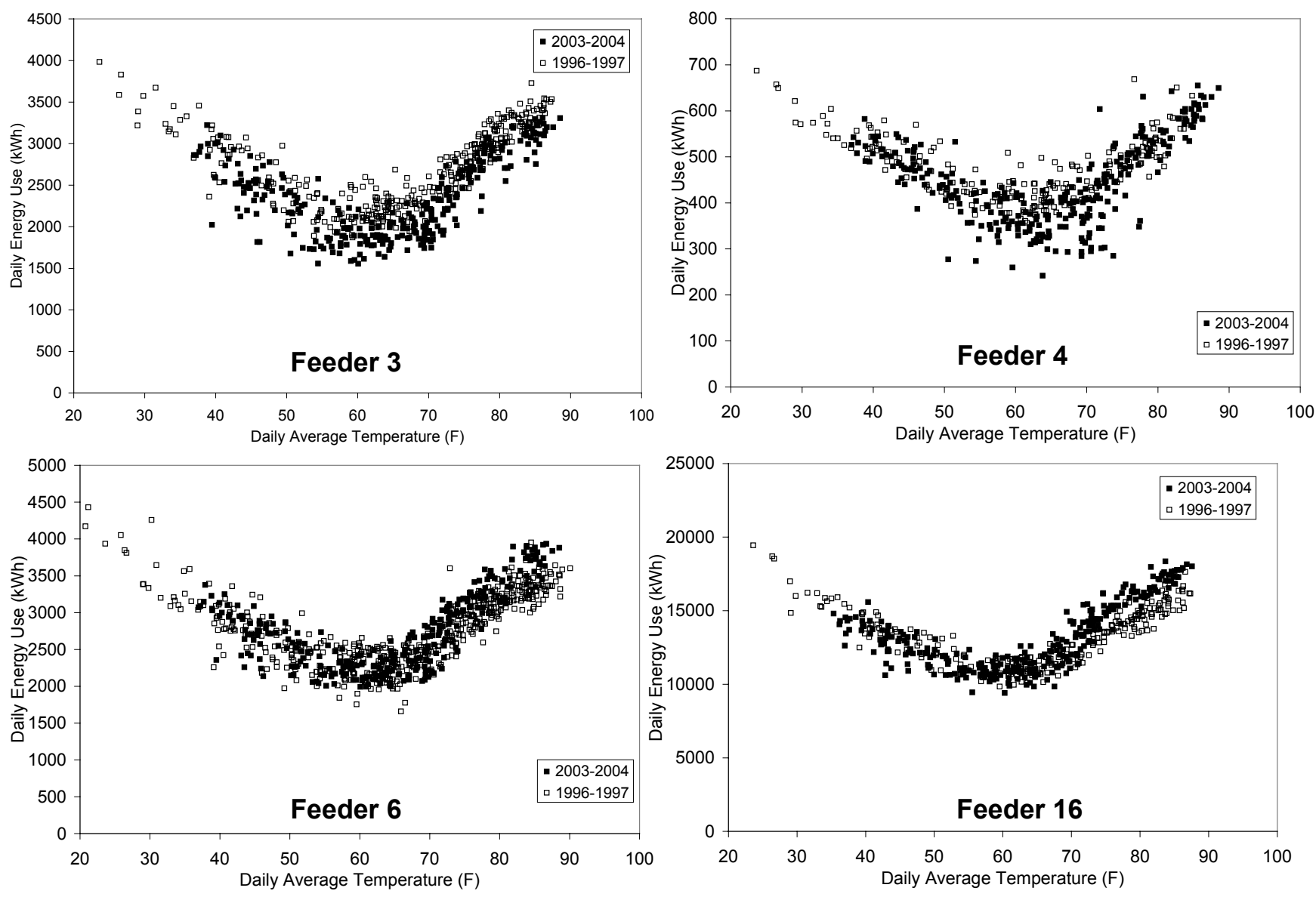

Figure C.6. Electricity use on four submetered feeders to Fort Polk family housing appears to have changed very little, based on comparison of 1996-1997 and 2003 - 2004 data sets.

We cannot be certain why the manual readings from the family housing meters and the 15-minute-interval data from 7 of 11 data loggers would be unreliable. However, we have a theory that explains what we see in the data. Our theory, suggested by Figure C.2, is that electrical distribution system circuits were switched in September 1999 and again in July 2000, creating a period between these dates when housing submeters did not capture all of the housing loads; and that after July 2000 large non-housing loads were being served through the housing submeters. It is also possible that some of the housing submeters are no longer functioning properly, especially since they are maintained by the Army and not the utility. This theory would also explain why the use of manual readings from the housing submeters as part of the M\&V procedures for the actual ESPC project was abandoned a few years into the project. 
For each of the four feeders with usable data, we fit daily electricity use data from 19961997 and 2003-2004 to a five-parameter function of daily average temperature using the technique described in our 1998 evaluation of the Fort Polk project (Hughes and Shonder 1998). This regression analysis allowed us to predict annual energy use for a typical year. If there have been no increases in energy use, then the TMY predictions from the two data sets should be roughly the same. Table C.1 shows the results of the regression analysis of 1996-1997 and 2003-2004 electricity use data for the four feeders.

Table C.1. Annual electricity use predicted for a TMY by regression analysis of 1996-1997 and 20032004 electricity use data for four submetered Fort Polk family housing feeders.

\begin{tabular}{cccc}
\hline Feeder & $\begin{array}{c}\text { TMY energy use } \\
\text { based on 1996- } \\
\text { 1997 data (kWh) }\end{array}$ & $\begin{array}{c}\text { TMY energy use } \\
\text { based on 2003-2004 } \\
\text { data }(\mathrm{kWh})\end{array}$ & $\begin{array}{c}\text { Percentage } \\
\text { change }\end{array}$ \\
\hline 3 & 977,428 & 882,651 & $-9.7 \%$ \\
4 & 176,601 & 166,838 & $-5.5 \%$ \\
6 & 999,035 & $1,037,816$ & $3.9 \%$ \\
16 & $4,763,891$ & $4,982,995$ & $4.6 \%$ \\
Total & $6,916,955$ & $7,070,300$ & $2.2 \%$ \\
\hline
\end{tabular}

The analysis indicates that energy use on some of the feeders has decreased, and on some it has increased. Some of the changes are undoubtedly due to changes in occupancy, for which we have no information. Overall, energy use for the four feeders has increased by $2.2 \%$ over 7 years. This is an annual rate of increase of just $0.3 \%$.

Based on this analysis of a large sample of Fort Polk's housing, we conclude that there have been only small increases in electricity use in Fort Polk's family housing since the retrofits were installed. The $0.3 \%$ annual increase is smaller than housing load growth predicted in the 1998 evaluation based on national averages at the time for plug load growth. Since in ESPC projects the ESCO is not accountable for plug load growth, it follows that the ESPC energy savings have persisted. 


\section{Appendix D: \\ Utility Bill Analysis to Determine Electrical Cost Savings}

In Appendix A we derived equations that predict pre- and post-retrofit electrical use in the North and South Fort areas of Fort Polk given base- $65^{\circ} \mathrm{F}$ heating and cooling degree days. Subtracting the post-retrofit electrical use from the pre-retrofit electrical use gives electrical savings as a function of heating and cooling degree days:

$\underline{\text { North Fort }}$

$$
\text { Monthly savings }(\mathrm{kWh})=75,722+372 \cdot \mathrm{HDD}+444 \cdot \mathrm{CDD}
$$

$\underline{\text { South Fort }}$

$$
\text { Monthly savings }(\mathrm{kWh})=800,529+1,389 \cdot \mathrm{HDD}+3,748 \cdot \mathrm{CDD}
$$

Likewise, from Appendix B we can derive equations for monthly peak demand savings as a function of monthly high and low temperatures:

\section{$\underline{\text { North Fort }}$}

Summer demand savings $(\mathrm{kW})=24.96 \cdot \mathrm{T}_{\max }-1,761.9$

Winter demand savings $(\mathrm{kW})=-75.57 \cdot \mathrm{T}_{\max }-193.44 \cdot \mathrm{T}_{\min }+13,113$

$\underline{\text { South Fort }}$

Summer demand savings $(\mathrm{kW})=175.08 \cdot \mathrm{T}_{\max }-11,147$

Winter demand savings $(\mathrm{kW})=-417.11 \cdot \mathrm{T}_{\max }-644.87 \cdot \mathrm{T}_{\min }+53,861$

Given these equations we can predict the demand and energy savings in any given month knowing the base $-65^{\circ} \mathrm{F}$ heating and cooling degree days that occurred, and the monthly high and low temperature. This provides a way of determining how much Fort Polk would have paid for electricity had the project not been implemented. For each month in the post-retrofit period, we estimate the energy and demand savings using equations (D.1) through (D.4). Adding the estimated energy savings to the actual billed energy use gives an estimate of what the energy use would have been without the project. Likewise adding the estimated demand savings to the actual billed peak demand gives an estimate of what demand would have been without the project. Then given energy use and demand without the project, we use the same rate schedule to estimate what the electric bill would have been in that month. 


\section{Electricity Rates}

In the period from June 1993 to June 2003, Fort Polk's serving electric utility has charged four different rates. These rates had two different structures. The LGS rate structures in effect through October 2001 included declining block rates for both demand and energy. Consider, for example, the LGS-15 rate in effect through June 1995. For demand, the first block of $60 \mathrm{~kW}$ was billed at $\$ 4.83$ per $\mathrm{kW}$, and the remaining demand was billed at $\$ 3.00$ per $\mathrm{kW}$. For energy, the first block of $30,000 \mathrm{kWh}$ was billed at 0.0436 per $\mathrm{kWh}$, the second block (up to 400 times the monthly peak demand) was billed at $\$ 0.0341$ per $\mathrm{kWh}$, and the remainder at $\$ 0.0249$ per $\mathrm{kWh}$. The LGS-16 and LGS-17 rates were similar, with slightly lower rates in all blocks.

In November 2001 Fort Polk was switched to the Small General Service Rate (GS-1S), which is a declining block rate for energy only. First, there is a customer charge of $\$ 9.89$ per month. The first block of energy - sized at $1575 \mathrm{kWh}$ plus 55 times the peak demand - is billed at $\$ 0.0918$ per $\mathrm{kWh}$; the second block, up to $24,500 \mathrm{kWh}$, is billed at $\$ 0.0475$ per $\mathrm{kWh}$. The charge for the remaining energy depends on the season. From November through April, the rate is $\$ 0.0288$ per $\mathrm{kWh}$, and from May through October the rate is $\$ 0.0335$ per $\mathrm{kWh}$.

Table D.1 presents the rates Fort Polk has paid and the periods during which these rates were in effect. In addition to the rates, Fort Polk's electricity bill depended on a number of riders as well. For example, according to the utility's Rider G, energy and demand charges are discounted by $5 \%$ in the South Fort bill because service is delivered at a primary line voltage higher than 13,800 volts, and Fort Polk owns and maintains all of the service transformers. Beginning in June 1996, a "Formula Rate Plan" took effect, which provides a per-kWh discount that varies from month to month.

Table D.1. Fort Polk Utility Rates

\begin{tabular}{ccccccc}
\hline Rate & $\begin{array}{c}\text { Effective } \\
\text { date }\end{array}$ & $\begin{array}{c}\text { 1st demand } \\
\text { charge, per } \\
\mathrm{kW}\end{array}$ & $\begin{array}{c}\text { 2nd demand } \\
\text { charge, per } \\
\mathrm{kW}\end{array}$ & $\begin{array}{c}\text { 1st energy } \\
\text { charge, per } \\
\mathrm{kWh}\end{array}$ & $\begin{array}{c}\text { 2nd energy } \\
\text { charge, per } \\
\mathrm{kWh}\end{array}$ & $\begin{array}{c}\text { 3rd energy } \\
\text { charge, per } \\
\mathrm{kWh}\end{array}$ \\
\hline LGS-15 & June-93 & $\$ 4.83$ & $\$ 3.00$ & $\$ .0436$ & $\$ .0341$ & $\$ .0250$ \\
LGS-16 & Jul-95 & $\$ 4.68$ & $\$ 2.92$ & $\$ .0442$ & $\$ .0330$ & $\$ .0240$ \\
LGS-17 & Oct-95 & $\$ 4.62$ & $\$ 2.87$ & $\$ .0417$ & $\$ .0326$ & $\$ .0239$ \\
GS-1S & Nov-04 & none & none & $\$ .0918$ & $\$ .0475$ & $\$ .0288 / \$ .0335$ \\
\hline
\end{tabular}

Interestingly, a high portion of Fort Polk's electricity bill depends not on the particular rate charged, but on the Fuel Cost Realignment rider. This is a per-kWh charge applied monthly that is intended to recover the utility's fuel costs. Over the 121 months of records available, the fuel adjustment charge ranged from $\$ 0.0125$ to $\$ 0.0540$ per $\mathrm{kWh}$. On average over this period, fuel adjustment costs accounted for $45 \%$ of the total bills. 


\section{An Example}

During the month of September 1996 - the first month after completion of the energy conservation retrofits - peak demand in the South Fort was 25,301 kW, with 13,112,400 $\mathrm{kWh}$ consumed. Fort Polk was paying the LGS-17 rate at the time. Table D.2 shows a breakdown of the bill for that month.

Table D.2. Breakdown of Fort Polk utility bill for September 1996

\begin{tabular}{llrc}
\hline \multicolumn{1}{c}{ Charge } & \multicolumn{1}{c}{ Calculation } & \multicolumn{1}{c}{ Value } \\
\hline First demand charge & $\$ 4.62 \times 60$ & $\$$ & 277.20 \\
Second demand charge & $\$ 2.87 \times(25,301-60)$ & $\$$ & $72,441.67$ \\
First energy charge & $\$ 0.0417 \times 30,000$ & $\$$ & $1,251.00$ \\
Second energy charge & $\$ 0.0326 \times(400 \times 25,301-30,000)$ & $\$$ & $328,947.04$ \\
Third energy charge & $\$ 0.0239 \times(13,112,400-400 \times 25,301)$ & $\$$ & $71,508.80$ \\
Subtotal, energy and demand & & $\mathbf{4 7 7 4 , 4 2 5 . 7 1}$ \\
Primary voltage discount & $-0.05 \times$ subtotal & $\$$ & $(23,721.29)$ \\
Fuel adjustment cost & $\$ 0.02493 \times 13,112,400$ & $\$$ & $326,892.13$ \\
Formula rate reduction & $-\$ 0.0001234 \times 13,112,400$ & $\$$ & $(16,179.52)$ \\
Total & & $\$ \mathbf{7 6 1 , 4 1 7 . 0 4}$ \\
\hline
\end{tabular}

Now, from weather records we find that the month of September 1996 had 5 heating degree days and 331 cooling degree days, and the high temperature for the month was $91.4^{\circ} \mathrm{F}$. From equation (C.2), the energy savings during this month is estimated as

$$
800,529+(1,389)(5)+(3,748)(331)=2,048,062 \mathrm{kWh} .
$$

Given that the actual electrical use for the month was $13,112,400 \mathrm{kWh}$, we can estimate that if the project had not been installed, the electrical use would have been $13,112,400+$ $2,048,062=15,160,462 \mathrm{kWh}$.

From Eq. (D.4a) the demand savings during the month is estimated as

$$
(175.08)(91.4)-11,147=4,855 \mathrm{~kW}
$$

So given that the actual peak demand was $25,301 \mathrm{~kW}$, we can estimate that had the energy conservation measures not been installed the peak demand for this month would have been $25,301+4855=30,156 \mathrm{~kW}$.

Now we use the same rates to calculate what the electrical bill would have been with a peak demand of $30,156 \mathrm{~kW}$ and an electrical use of 15,160,462 $\mathrm{kWh}$. The calculations are summarized in Table D.3. 
Table D.3. Calculated Fort Polk electricity cost for September 1996 without savings

\begin{tabular}{llrc}
\hline First demand charge & $\$ 4.62 \times 60$ & $\$$ & 277.20 \\
\hline Second demand charge & $\$ 2.87 \times(30,156-60)$ & $\$$ & $86,375.52$ \\
First energy charge & $\$ 0.0417 \times 30,000$ & $\$$ & $1,251.00$ \\
Second energy charge & $\$ 0.0326 \times(400 \times 30,156-30,000)$ & $\$$ & $392,256.24$ \\
Third energy charge & $\$ 0.0239 \times(15,160,462-400 \times 30,156)$ & $\$ 74,043.68$ \\
Subtotal, energy and demand & & $\$$ & $\mathbf{5 5 4 , 2 0 3 . 6 4}$ \\
Primary voltage discount & $-0.05 \times$ subtotal & $\$$ & $(27,710.18)$ \\
Fuel adjustment cost & $\$ 0.02493 \times 15,160,462$ & $\$$ & $377,950.32$ \\
Formula rate reduction & $-\$ .0001234 \times 15,160,462$ & $\$$ & $(18,706.65)$ \\
Total & & $\$ \mathbf{8 8 5 , 7 3 7 . 1 3}$ \\
\hline
\end{tabular}

Now given the results of Table D.2 and D.3, we define the energy savings in September 1996 to be $\$ 885,737.13-\$ 761,417.04=\$ 124,320.09$. 